\title{
THE GROWTH RATE OF THE HAKE, MERLUCCIUS MERLUCCIUS (L.), IN THE CLYDE AND OTHER SCOTTISH SEA AREAS
}

\author{
By T. B. Bagenal
}

The Marine Station, Millport

(Plate I and Text-figs. I-I3)

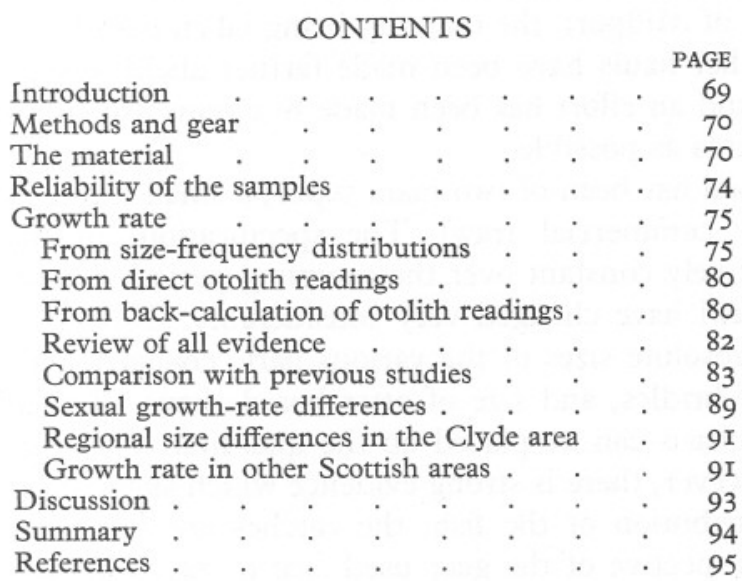

\section{INTRODUCTION}

Hake belonging to the genus Merluccius are large fish often growing to over a metre in length; they are predators, being well streamlined and armed with formidable teeth; they feed pelagically on smaller fish of their own and other species. Of the various species distributed round the ocean basins, the European Hake, M. merluccius (L.), ranges from Lofoten on the coast of Norway, to Dakar on the African west coast; it is found most plentifully along the edge of the continental shelf of Western Europe but also extends into the Mediterranean and North Sea, while stragglers occasionally range as far as Iceland.

In the Clyde area the hake is common in deep water, being found on the east side of Arran, in Kilbrennan Sound, and in Loch Fyne as far up as Inveraray. Elsewhere, in shallower water, it is less frequent and only smaller specimens are taken. The main fishery for hake is in the area off Tarbert, where they are caught on long lines set in mid water. 
The most important papers on the biology of the hake are those of Hickling (1927-33), who made an intensive study primarily of hake from S.W. Ireland, and Belloc (1923, I929), who worked on the French and North African coasts, while Hart (1948) has published a review in which he has summarized a number of scattered works on the distribution and biology of the species. The present paper describes the results of an investigation on the growth rate of hake in the Clyde area.

\section{Methods AND Gear}

Since June I 949 trawl hauls have been taken at irregular intervals in the Clyde area from M.F.V. Calanus, and the lengths of the hake obtained have been measured to the nearest centimetre below. Most of the hauls have been made in the vicinity of Millport, the majority being taken between Great Cumbrae and Bute. Other hauls have been made farther afield whenever the opportunity arose, and an effort has been made to obtain fish from as many parts of the Clyde area as possible.

The gear used has been of two main types; a small-mesh cotton trawl and a larger-mesh commercial trawl. The specifications of the former have remained relatively constant over the sampling period, whereas those of the large-mesh trawl have changed very considerably. Not only have the proportions and absolute sizes of the various parts changed, but also the mesh size, length of bridles, and size of otter boards have all changed. For this reason no emphasis can be placed on the quantitative aspect of the catches obtained. However, there is strong evidence which suggests that for the sizefrequency distribution of the fish, the catches are reliable samples of the population irrespective of the gear used (see p. 74). The sampling of small hake was seriously prejudiced by the loss of the first small-mesh trawl on Io January I950, and hake were not again caught with this kind of gear until I5 September I950.

\section{The Material}

Between June I949 and March I953, 2250 hake were caught on sixty-five occasions. Details of the hauls are given in Table I and are separated into six populations on the basis of their length distributions.

Population $a$ has only been caught during the winter of 1952-53, and consists of forty-six fish believed to have been hatched in 1952 .

Population $b$ consists of ninety-four fish believed to have been hatched in I95I.

Population $c$ first appeared in September I95I when one fish of $30 \mathrm{~cm}$. was caught. Altogether only fifty-six hake of this population have been caught.

Population $d$ is the most important group and has provided the majority of the fish, I55I having been caught during the sampling period. These fish, 


\section{Table I. Hake Populations $a-f$, Caught in the Clyde Area FROM JULY I949 TO FEBRUARY I953}

\begin{tabular}{|c|c|c|c|c|c|c|}
\hline \multirow[t]{2}{*}{ Date } & $\begin{array}{l}\text { No. in } \\
\text { sample }\end{array}$ & $\begin{array}{l}\text { Mean } \\
\text { length }\end{array}$ & $\begin{array}{l}\text { Length } \\
\text { range }\end{array}$ & $\begin{array}{l}\text { Standard } \\
\text { deviation }\end{array}$ & Position of haul & Gear \\
\hline & \multicolumn{6}{|c|}{ Population a } \\
\hline $\begin{array}{l}1952 \\
\text { I8. xii. }\end{array}$ & 40 & $10 \cdot 0$ & $7-14$ & I.99 & Tarbert & Large mesh \\
\hline \multicolumn{7}{|l|}{1953} \\
\hline $\begin{array}{l}\text { II. ii. } \\
\text { I6. ii. }\end{array}$ & $\begin{array}{l}5 \\
I\end{array}$ & $\begin{array}{l}13 \cdot 0 \\
16\end{array}$ & $\stackrel{\mathrm{I} 2-\mathrm{I} 4}{-}$ & 二 & $\begin{array}{l}\text { E. side of Arran } \\
\text { Bute Channel }\end{array}$ & $\begin{array}{l}\text { Large mesh } \\
\text { Large mesh }\end{array}$ \\
\hline \multirow{2}{*}{\multicolumn{7}{|c|}{ Population $b$}} \\
\hline $1952 \ldots$ & & & & & & \\
\hline 4. vii. & 3 & $36 \cdot 0$ & $33-39$ & - & Bute Channel & Small mesh \\
\hline 4. xii. & I & 39 & & - & Bute Channel & Small mesh \\
\hline I8. xii. & I3 & $24 \cdot 9$ & $22-28$ & $r \cdot 90$ & Tarbert & Large mesh \\
\hline I9. xii. & 우 2 & $36 \cdot 5$ & $30-43$ & - & Strachur to & Large mesh \\
\hline I9. xii. & $\sigma^{*} \mathrm{I}$ & $3 \mathrm{I}$ & - & - & Inveraray & Large mesh \\
\hline \multicolumn{7}{|l|}{1953.} \\
\hline I5. i. & 2 & 37.5 & $35-40$ & - & Bute Channel & Small mesh \\
\hline I6. i. & ㅇ 2 & $33 \cdot 5$ & $33-34$ & - & Mountstuart & Large mesh \\
\hline I6. i. & $0^{1} 2$ & $34^{\circ} 0$ & $33-35$ & - & Mountstuart & Large mesh \\
\hline 20. i. & I & 36 & - & - & S.E. of Pladda & Large mesh \\
\hline 2I. i. & $0^{*} 2$ & $35 \cdot 0$ & - & - & S.W. of Sanda & Large mesh \\
\hline 2I. i. & \% 2 & 33.5 & $33-34$ & - & E. of Ailsa Craig & Large mesh \\
\hline 5. ii. & 2 & 38 & דצ אנת & - & Mountstuart & Large mesh \\
\hline II. ii. & q 2 & $37 \cdot 5$ & $36-39$ & - & E. side of Arran & Large mesh \\
\hline I6. ii. & 우 3 & $36 \cdot 3$ & $34-38$ & - & Bute Channel & Large mesh \\
\hline I8. ii. & ㅇ 33 & $32 \cdot 5$ & $28-39$ & $2 \cdot 59$ & Off Ardrossan & Large mesh \\
\hline I8. ii. & 023 & $34 \cdot 2$ & $29-40$ & $2 \cdot 56$ & Off Ardrossan & Large mesh \\
\hline \multirow{2}{*}{\multicolumn{7}{|c|}{ Population c }} \\
\hline I95I vii & & & & & & \\
\hline 13. xii. & I & 34 & - & - & Mountstuart & Large mesh \\
\hline \multicolumn{7}{|l|}{1952} \\
\hline I4. iii. & 4 & $4 \mathrm{r} \cdot \mathrm{O}$ & $40-42$ & - & Mountstuart & Large mesh \\
\hline 18. xii. & ㅇ 3 & $56 \cdot 3$ & $5 \mathrm{I}-60$ & - & Tarbert & Large mesh \\
\hline & 今 4 & $50 \cdot 0$ & $45-53$ & - & Tarbert & Large mesh \\
\hline I9. xii. & 15 & $48 \cdot 3$ & $45-53$ & $2 \cdot 19$ & Strachur to & Large mesh \\
\hline & ô II & $47 \cdot 9$ & $39-54$ & $4 \cdot 16$ & Inveraray & Large mesh \\
\hline & \multicolumn{6}{|c|}{1953.} \\
\hline I6. $\mathrm{i}$. & I & 49 & - & - & $\begin{array}{l}\text { Bute Channel } \\
\text { Mountstuart }\end{array}$ & $\begin{array}{l}\text { Small mesh } \\
\text { Large mesh }\end{array}$ \\
\hline Io. ii. & 오 $\mathrm{I}$ & 56 & - & - & Holy Isle & Large mesh \\
\hline I3. ii. & ㅇ 4 & $51 \cdot 0$ & $47-55$ & - & Tarbert & Large mesh \\
\hline & 03 & $50 \cdot 7$ & $50-5 \mathrm{I}$ & - & Tarbert & Large mesh \\
\hline & 8 & $55 \cdot \mathrm{I}$ & $51-59$ & $3 \cdot 36$ & Tarbert & Large mesh \\
\hline \multicolumn{7}{|c|}{ Population d } \\
\hline 1949 & & & & & & \\
\hline 14. $x$. & 137 & $8 \cdot \mathrm{I}$ & $6-10$ & 0.99 & Bute Channel & Small mesh \\
\hline 17. $x$. & 160 & $7 \cdot 6$ & $5-10$ & $\mathrm{I} \cdot \mathrm{OI}$ & Bute Channel & Small mesh \\
\hline 26. $x$. & 85 & $7 \cdot 9$ & 6-10 & $\mathrm{I} \cdot 05$ & Loch Fyne & Small mesh \\
\hline 29. $x$ : & 38 & $9 \cdot 5$ & $6-13$ & I. 27 & Bute Channel & Small mesh \\
\hline I5. xi. & 43 & II. 7 & $9-14$ & $\mathrm{I} \cdot 2 \mathrm{I}$ & Bute Channel & Small mesh \\
\hline \multirow[t]{2}{*}{ 22. xi. } & 17 & $\mathrm{I} 2 \cdot 2$ & 10-15 & $\mathrm{I} \cdot 52$ & Wemyss Bay & Small mesh \\
\hline & 125 & I2.I & $8-18$ & $I \cdot 70$ & Bute Channel & Small mesh \\
\hline 28. xi. & 28 & $\mathrm{I} 2 \cdot 2$ & $6-16$ & $2 \cdot 33$ & Bute Channel & Small mesh \\
\hline \multicolumn{7}{|l|}{150} \\
\hline I8. i. & 3 & I5.7 & $14-19$ & - & Bute Channel & Large mesh \\
\hline I9. i. & 3 & 16.0 & $15-17$ & - & Bute Channel & Large mesh \\
\hline
\end{tabular}




\section{TABLE I (cont.)}

$\begin{array}{ccc}\text { Dote in } & \begin{array}{c}\text { Mean } \\ \text { sample length }\end{array} & \begin{array}{c}\text { Length Standard } \\ \text { range deviation Position of haul } \\ \text { Population d (cont.) }\end{array} \text { Gear }\end{array}$

\begin{tabular}{|c|c|c|c|c|c|c|}
\hline \multirow{2}{*}{\multicolumn{7}{|c|}{ I950 }} \\
\hline 25. i. & I & & - & - & Mountstuart & I arge mech \\
\hline 27. i. & 5 & $16 \cdot 8$ & I4-I9 & - & $\begin{array}{l}\text { Mountstuart } \\
\text { Mountstuart }\end{array}$ & $\begin{array}{l}\text { Large mesh } \\
\text { Large mesh }\end{array}$ \\
\hline 7. ii. & 9 & $17 \cdot 4$ & $14-22$ & $2 \cdot 88$ & $\begin{array}{l}\text { Mountstuart } \\
\text { Mountstuart }\end{array}$ & Large mesh \\
\hline I0. ii. & 5 & $20 \cdot 0$ & I9-2I & - & $\begin{array}{l}\text { Mountstuart } \\
\text { Mountstuart }\end{array}$ & $\begin{array}{l}\text { Large mesh } \\
\text { Large mesh }\end{array}$ \\
\hline I5. ii. & I & 22 & - & - & Mountstuart & $\begin{array}{l}\text { Large mesh } \\
\text { Large mesh }\end{array}$ \\
\hline I7. ii. & 8 & 15.9 & I $2-20$ & $2 \cdot 70$ & Loch Fyne & Large mesh \\
\hline 20. ii. & 6 & $18 \cdot 0$ & I6-2I & $I \cdot 79$ & Bute Channel & Large mesh \\
\hline 20. ii. & 4 & $18 \cdot 0$ & I6-19 & - & Mountstuart & Large mesh \\
\hline 27. ii. & I & I8 & - & - & Mountstuart & Large mesh \\
\hline 9. iii. & I7 & I6.5 & $I_{3}-2 I$ & $2 \cdot 24$ & Kilbrennan Sound & Large mesh \\
\hline 2I. iii. & I3 & $17 \cdot 5$ & I5-19 & I. 39 & Ailsa Craig & Large mesh \\
\hline 28. iii. & 46 & I9. I & I5-25 & $2 \cdot 20$ & Inchmarnock Water & Large mesh \\
\hline 3I. v. & 3 & $20 \cdot 0$ & I9-2I & - & Mountstuart & Large mesh \\
\hline I5. ix. & 32 & $27 \cdot 6$ & I8-34 & 3.42 & Mountstuart & Smail mesh \\
\hline I5. ix. & 37 & $27 \cdot 9$ & $2 \mathrm{I}-34$ & $2 \cdot 93$ & Mountstuart & Large mesh \\
\hline 20. xi. & 23 & $34 \cdot 8$ & $27-4 \mathrm{I}$ & 3.43 & Mountstuart & Large mesh \\
\hline I95I & & & & & & \\
\hline I5. i. & 3 & $39 \cdot 7$ & $37-42$ & - & Mountstuart & Large mesh \\
\hline 7. ii. & 6 & $34 \cdot 0$ & $25-42$ & $5 \cdot 83$ & Knock Castle & Large mesh \\
\hline I2. ii. & 99 & $36 \cdot 6$ & $30-44$ & 3.09 & Mountstuart & Large mesh \\
\hline 2I. ii. & 4I & $37 \cdot 2$ & $27-44$ & $3 \cdot 79$ & Mountstuart & Large mesh \\
\hline I8. iv. & 24 & $39 \cdot I$ & $28-45$ & $3.5 \mathrm{I}$ & Mountstuart & Large mesh \\
\hline 23. v. & 26 & $38 \cdot 2$ & $33-48$ & 3.52 & Mountstuart & Large mesh \\
\hline 23. v: & ro & $39 \cdot I$ & $3 I-45$ & $4 \cdot 48$ & Knock Castle & Large mesh \\
\hline II. vi. & 29 & $40 \cdot 4$ & $33-47$ & 3.50 & Mountstuart & Large mesh \\
\hline 28. vi. & 7 & $40 \cdot I$ & $36-44$ & 2.91 & Mountstuart & Large mesh \\
\hline 28. vi. & I9 & $4 \mathrm{I} \cdot \mathrm{O}$ & $36-48$ & $I \cdot I 7$ & Bute Channel & Large mesh \\
\hline 10. vii. & I7 & $40 \cdot 5$ & $35-47$ & 3.47 & Mountstuart & Large mesh \\
\hline I4. viii. & I6 & $4 I \cdot 3$ & $34-47$ & $3 \cdot 48$ & Mountstuart & Large mesh \\
\hline 28. viii. & 2 & $40 \cdot 5$ & $35-46$ & - & Mountstuart & Large mesh \\
\hline II. ix. & 4 & $46 \cdot 8$ & $45-50$ & - & Mountstuart & Large mesh \\
\hline I2. ix. & 2 & 38.5 & $33-44$ & - & Mountstuart & Large mesh \\
\hline I5. $x$ : & 5 & $49 \cdot 6$ & $45-54$ & - & Bute Channel & Large mesh \\
\hline 21. xi. & 5 & $47 \cdot 0$ & $42-50$ & - & Mountstuart & Large mesh \\
\hline 22. xi. & 3 & $5 I \cdot 3$ & $49-55$ & - & Bute Channel & Small mesh \\
\hline I952 & & & & & & \\
\hline 8. i.: & I & 55 & - & - & Mountstuart & Small mesh \\
\hline I2. ii. & 9 & $55^{\circ} \cdot 2$ & $52-60$ & 3.03 & Mountstuart & Small mesh \\
\hline 20. ii. & 6 & $55 \cdot 7$ & $5 \mathrm{I}-6 \mathrm{I}$ & 3.50 & Bute Channel & Small mesh \\
\hline I4. iii. & 8 & $53 \cdot 0$ & $49-59$ & 2.93 & Mountstuart & Large mesh \\
\hline 8. iv. & 6 & $55 \cdot 3$ & $50-63$ & $5 \cdot 16$ & Mountstuart & Large mesh \\
\hline I4. iv. & 6 & $53 \cdot 8$ & $52-59$ & $2 \cdot 7 \mathrm{I}$ & Bute Channel & Small mesh \\
\hline 23. v. & I & 50 & - & - & Mountstuart & Large mesh \\
\hline 4. vii. & 2 & $56 \cdot 5$ & $53-60$ & - & Bute Channel & Small mesh \\
\hline II. xii. & 우 I4 & 68.9 & $63-75$ & $3 \cdot 24$ & Off Corrie, Arran & Large mesh \\
\hline II. xii. & 03 & $5 \mathrm{I} \cdot 7$ & $5 \mathrm{I}-53$ & - & Off Corrie, Arran & Large mesh \\
\hline I8. xii. & 우 16 & $68 \cdot I$ & $6 \mathrm{I}-75$ & $3 \cdot 98$ & Tarbert & Large mesh \\
\hline I8. xii. & o 18 & $63 \cdot 3$ & $55-72$ & $4 \cdot 30$ & Tarbert & Large mesh \\
\hline I9. xii. & 우 59 & $62 \cdot 6$ & $53-72$ & 4.43 & Strachur to & Large mesh \\
\hline I9. xii. & ô 20 & $59 \cdot 3$ & $51-67$ & 4.63 & Inveraray & Large mesh \\
\hline I953 & & & & & & \\
\hline I5. i. & I & 66 & - & - & Bute Channel & Small mesh \\
\hline 22. i. & 우 & $68 \cdot 3$ & $67-69$ & - & Kilbrennan Sound & Large mesh \\
\hline Io. ii. & 2 & $68 \cdot 5$ & $68-69$ & - & E. side of Arran & Large mesh \\
\hline II. ii. & 우 6 & $71 \cdot 0$ & $65-75$ & $3 \cdot 74$ & E. side of Arran & Large mesh \\
\hline II. ii. & 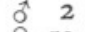 & $69 \cdot 5$ & $69-70$ & - & E. side of Arran & Large mesh \\
\hline I3. ii. & 우 50 & $69 \cdot 5$ & $60-77$ & 4.50 & Tarbert & Large mesh \\
\hline I3. ii. & क 27 & 63.7 & $58-69$ & $3 \cdot 24$ & Tarbert & Large mesh \\
\hline I3. ii. & 122 & $67 \cdot 8$ & $57-77$ & 3.78 & Tarbert & Large mesh \\
\hline I6. ii. & I & 68 & - & - & Bute Channel & Large mesh \\
\hline
\end{tabular}




\begin{tabular}{|c|c|c|c|c|c|c|}
\hline Date & $\begin{array}{l}\text { No. in } \\
\text { sample }\end{array}$ & $\begin{array}{l}\text { Mean } \\
\text { length }\end{array}$ & $\begin{array}{l}\text { Length } \\
\text { range }\end{array}$ & $\begin{array}{l}\text { tandard } \\
\text { leviation }\end{array}$ & Position of haul & Gear \\
\hline \multicolumn{7}{|c|}{ Population e } \\
\hline $\begin{array}{l}\text { I949, vii. } \\
\text { 6. }\end{array}$ & 6 & I8.3 & $14-22$ & 3.01 & Inchmarnock Water & Large mesh \\
\hline 4. $x$. & 4 & $3 I \cdot 5$ & $30-33$ & - & Bute Channel & Large mesh \\
\hline 22. xi. & I & 34 & - & - & Wemyss Bay & Small mesh \\
\hline 2. xii. & 4 & $30 \cdot 3$ & $26-33$ & - & Off Ardrossan & Large mesh \\
\hline \multicolumn{7}{|l|}{ I950 } \\
\hline 25. i. & $\mathrm{I} 4$ & $38 \cdot 6$ & $33-45$ & $3 \cdot 76$ & Mountstuart & Large mesh \\
\hline 27. i. & 53 & $37 \cdot 6$ & $3 I-47$ & 3.95 & Mountstuart & Large mesh \\
\hline 7. ii. & I9 & $40 \cdot 4$ & $32-46$ & 4.00 & Mountstuart & Large mesh \\
\hline ro. ii. & 58 & $38 \cdot 2$ & $27-51$ & $4 \cdot 65$ & Mountstuart & Large mesh \\
\hline I5. ii. & 56 & $39 \cdot 7$ & $33-47$ & $3 \cdot 34$ & Mountstuart & Large mesh \\
\hline I7. ii. & I2 & $44 \cdot 4$ & $39-50$ & 3.73 & Loch Fyne & Large mesh \\
\hline 20. ii. & 6 & $4 \mathrm{I} \cdot 0$ & $36-50$ & 4.82 & Bute Channel & Large mesh \\
\hline 20. ii. & 46 & $38 \cdot 6$ & $28-48$ & $4 \cdot 48$ & Mountstuart & Large mesh \\
\hline 27. ii. & 42 & $39 \cdot 0$ & $3 I-46$ & $3 \cdot 26$ & Mountstuart & Large mesh \\
\hline 2r. iii. & 29 & $36 \cdot 7$ & $30-47$ & 3.91 & Ailsa Craig & Large mesh \\
\hline 3r. v. & I4 & $40 \cdot 9$ & $3 I-46$ & 4.15 & Mountstuart & Large mesh \\
\hline I5. ix. & 7 & $46 \cdot 6$ & $4 I-52$ & $4 \cdot 35$ & Mountstuart & Small mesh \\
\hline I5. ix. & II & $46 \cdot 5$ & $38-52$ & 4.52 & Mountstuart & Large mesh \\
\hline 20. xi. & 4 & $50 \cdot 5$ & $47-55$ & - & Mountstuart & Large mesh \\
\hline \multicolumn{7}{|l|}{ I95 I } \\
\hline I5. i. & 2 & $5 \mathrm{I} \cdot 5$ & $47-56$ & - & Mountstuart & Large mesh \\
\hline I2. ii. & 3 & $52 \cdot 7$ & $49-60$ & - & Mountstuart & Large mesh \\
\hline 2I. ii. & 6 & $5 \mathrm{I} \cdot 5$ & $47-55$ & $2 \cdot 8 \mathrm{I}$ & Mountstuart & Large mesh \\
\hline Ir. vi. & I & 61 & - & - & Mountstuart & Large mesh \\
\hline Io. vii. & 2 & $6 \mathrm{I} \cdot 0$ & $60-62$ & - & Mountstuart & Large mesh \\
\hline I5. $\mathrm{x}$. & I & $6 \mathrm{I}$ & - & - & Bute Channel & Large mesh \\
\hline II. xii. & I & 62 & - & - & Fairlie Channel & Small mesh \\
\hline \multicolumn{7}{|l|}{ I952 } \\
\hline II. xii. & ㅇ 3 & $83 \cdot 3$ & $83-84$ & - & Off Sannox, Arran & Large mesh \\
\hline II. xii. & o 3 & $70 \cdot 3$ & $68-72$ & - & Off Sannox, Arran & Large mesh \\
\hline I8. xii. & o & 84.0 & $82-86$ & - & Tarbert & Large mesh \\
\hline I8. xii. & 03 & $75 \cdot 0$ & $73-78$ & - & Tarbert & Large mesh \\
\hline I9. xii. & ㅇ 5 & $75 \cdot 8$ & $71-80$ & - & Strachur to & Large mesh \\
\hline I9. xii. & o 1 & 73 & - & - & Inveraray & Large mesh \\
\hline \multicolumn{7}{|l|}{ r953. } \\
\hline 22. i. & $q$ & $76 \cdot 0$ & $75-77$ & - & Kilbrennan Sound & Large mesh \\
\hline Io. ii. & $\hat{0} \quad I$ & 82 & - & - & Off Holy Isle & Large mesh \\
\hline II. ii. & 우 2 & $84 \cdot 5$ & $82-87$ & - & Off Sannox, Arran & Large mesh \\
\hline I3. ii. & 우 7 & $80 \cdot 0$ & $74-86$ & 4.04 & Tarbert & Large mesh \\
\hline I3. ii. & ơ 7 & $73 \cdot 3$ & $7 \mathrm{I}-77$ & $\mathrm{I} \cdot 98$ & Tarbert & Large mesh \\
\hline I3. ii. & 34 & $77 \cdot 9$ & $72-88$ & $4 \cdot 28$ & Tarbert & Large mesh \\
\hline I6. ii. & 우 1 & 77 & - & - & Mountstuart & Large mesh \\
\hline
\end{tabular}

Population $f$

\begin{tabular}{|c|c|c|c|c|c|c|}
\hline $\begin{array}{l}\text { I949 } \\
6 . \text { vii. } \\
6 . \text { vii. }\end{array}$ & $\begin{array}{l}2 \\
2\end{array}$ & $\begin{array}{l}4 I \cdot 5 \\
62 \cdot 5\end{array}$ & $\begin{array}{l}38-45 \\
62-63\end{array}$ & 二 & $\begin{array}{l}\text { Inchmarnock Water } \\
\text { Inchmarnock Water }\end{array}$ & $\begin{array}{l}\text { Large mesh } \\
\text { Large mesh }\end{array}$ \\
\hline \multicolumn{7}{|l|}{ I950 } \\
\hline I9. i. & I & 90 & - & - & Bute Channel & Large mesh \\
\hline I7. ii. & 6 & $60 \cdot 8$ & $56-65$ & $3 \cdot 3 \mathrm{I}$ & Loch Fyne & Large mesh \\
\hline I7. ii. & 2 & $7 \mathrm{I}$ & - & - & Loch Fyne & Large mesh \\
\hline I7. ii. & IO & $80 \cdot 0$ & $75-87$ & 3.94 & Loch Fyne & Large mesh \\
\hline 20. ii. & I & 58 & - & - & Mountstuart & Large mesh \\
\hline 27. ii. & I & 54 & - & - & Mountstuart & Large mesh \\
\hline \multicolumn{7}{|l|}{ 1953. } \\
\hline 22. i. & 4 & $103 \cdot 0$ & 93-I IO & - & Kilbrennan Sound & Large mesh \\
\hline II. ii. & I & 92 & - & - & Off Sannox, Arran & Large mesh \\
\hline
\end{tabular}


which are believed to have been hatched during the summer of 1949, were first caught during October of that year, when they had reached a mean length of $8 \mathrm{~cm}$., and ranged from 5 to $10 \mathrm{~cm}$. The catches obtained at this time are of very great interest as hake of this size had not been caught before in any quantity.

Post-larval hake of under $2 \mathrm{~cm}$. are well known; they have been described by Schmidt (1907) and reported from the Plymouth area (Clark, I920; Russell, 1930-7; Corbin, 1948), and from S.W. Ireland (Schmidt, I909; Hickling, 1933). However, very little indeed is known about the adolescent post-larval stage; Hickling (1933) only records nineteen fish of $10 \mathrm{~cm}$. and less, which he himself caught in I932. During the autumn of 1949,452 young hake of this size were caught in the Clyde area. The good catches of this year class ended in January 1950 owing to the loss of the small-mesh trawl, although some of these fish have been caught almost every month up to the end of the sampling period.

Population $e$ consists of 473 fish which hatched in 1948, growing to $18 \mathrm{~cm}$. by June 1949 and $78 \mathrm{~cm}$. by February 1953 .

Population $f$ consists of all fish longer than those that fit into population $e$. There is no evidence that they are a homogeneous collection, and they have been listed together only for convenience; they do not contribute materially to the results.

\section{RELIABILITY OF THE SAMPLeS}

If fish measurements are to be used for the determination of growth rate it is essential that the catches should give an adequate indication of the sizefrequency distributions of the populations. To test the reliability of the samples three series of hauls were considered and the means within each series compared; in no comparison was a significant difference found.

Series I is of three hauls taken with the small-mesh trawl in Bute Channel on 17 October 1949. The data are given in Table II, and Text-fig. I; there is no significant evidence that it was not the same population that was sampled in each haul.

Series II compares two hauls taken with the large-mesh trawl off Inveraray on I9 December 1952. The data are given in Table III and Text-fig. 2; again the same population has been sampled in both hauls.

Series III, caught on I5 September I950, and given in Table IV and Text-fig. 3 , shows that the two kinds of gear used may be relied upon to give comparable samples from the same population, provided the fish are large enough not to be selected by the size of mesh. The large-mesh trawl caught thirty-seven fish with a mean length of $27.9 \mathrm{~cm}$., while the small-mesh gear obtained thirty-two with a mean length of $27 \cdot 6 \mathrm{~cm}$. 


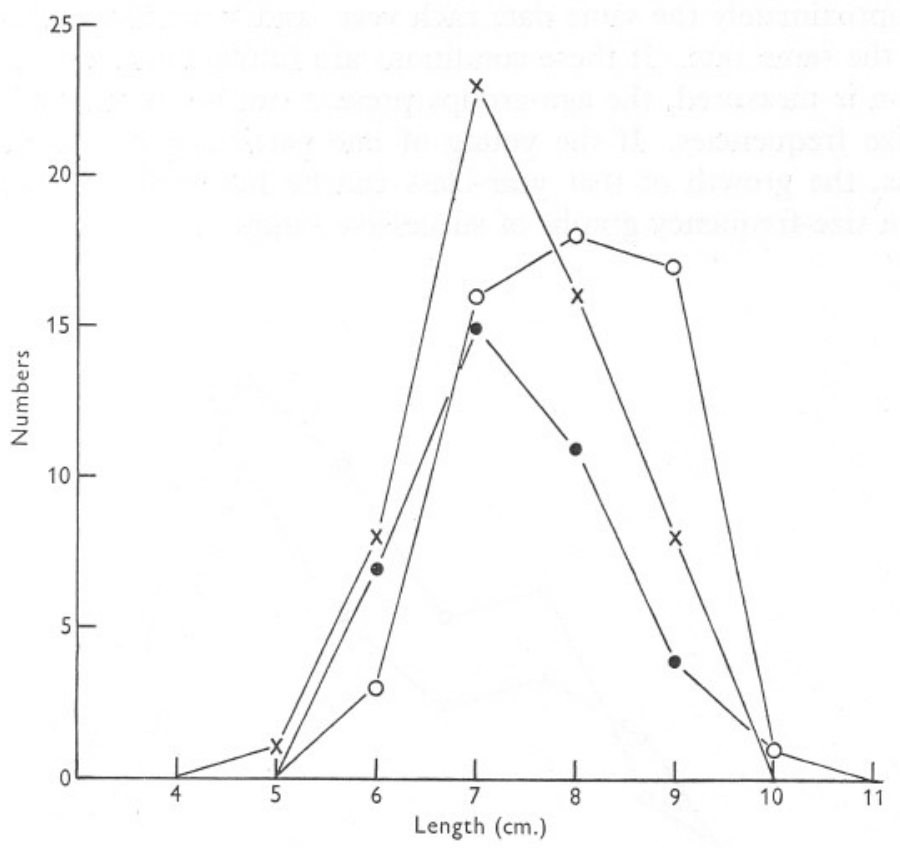

Text-fig. I. Length-frequency distributions of hake taken in series I. $\times$, haul I; o, haul II; 9 , haul III.

Table II. Series I Size-Frequency Distribution, ILLUSTRATED IN TEXT-FIG. I

$\begin{array}{cccc}\begin{array}{c}\text { Length } \\ \text { (cm.) }\end{array} & \overbrace{\text { Haul I }} & \text { Haul II } & \text { Haul III } \\ 5 & \text { I } & - & - \\ 6 & 8 & 3 & 7 \\ 7 & 23 & \text { I6 } & \text { I5 } \\ 8 & \text { I6 } & \text { I8 } & \text { II } \\ 9 & 8 & 17 & 4 \\ \text { I0 } & - & \text { I } & \text { I } \\ \text { Total } & 56 & 55 & 38 \\ \text { Mean } & 7 \cdot 4 & 7 \cdot 9 & 7 \cdot 4\end{array}$

Growth Rate

The growth rate of the Clyde hake has been determined by Petersen's method, based on size-frequency distributions, and confirmed by examination of the otoliths of the fish caught during December 1952 and January and February 1953.

\section{From Size-Frequency Distributions}

Petersen's method of age determination and deduction of the growth rate depend upon two conditions: first, that the fish spawn during a limited period 
and at approximately the same date each year; and secondly, that they grow at about the same rate. If these conditions are fulfilled and a sample of the population is measured, the age-groups present can be found by inspection of the size frequencies. If the young of one particular year are especially numerous, the growth of that year-class can be followed over a period of time from size-frequency graphs of successive samples.

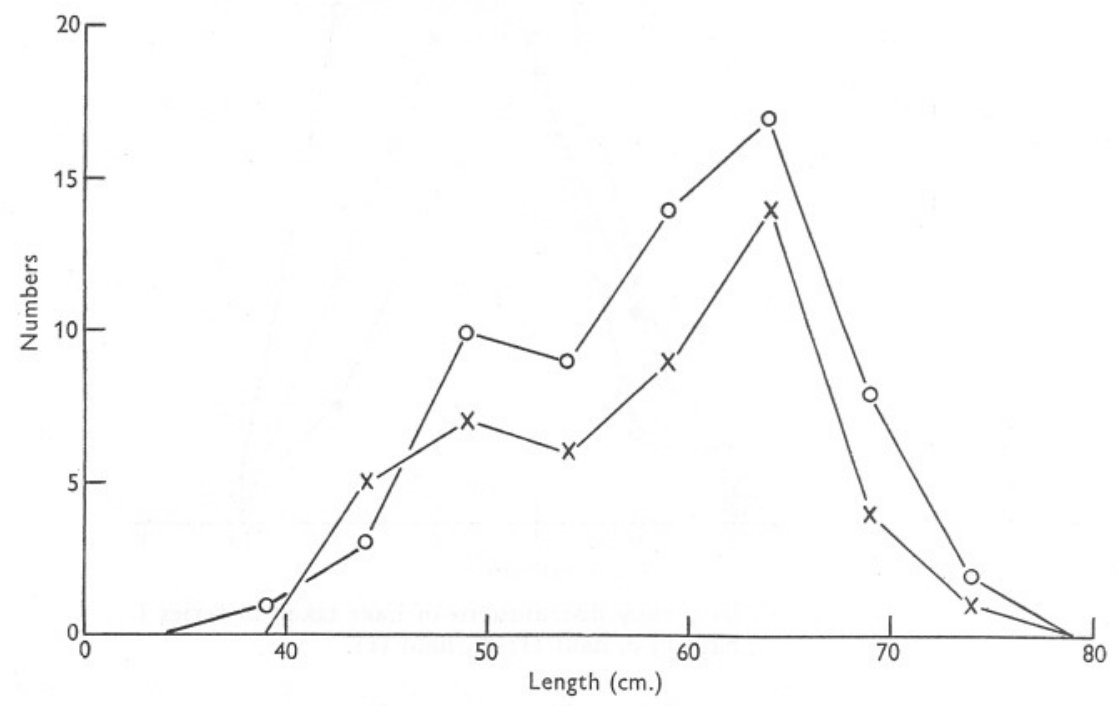

Text-fig. 2. Length-frequency distributions of hake taken in series II. $\times$, haul I; o, haul II.

Table III. Series II Size-Frequency Distribution, ILLUSTRATED IN TeXT-FIG. 2

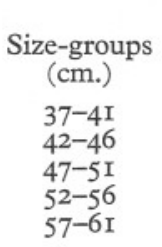

$\overbrace{\text { Haul I }}^{\text {Number of hake }} \underbrace{\text { II }}_{\text {Haul II }}$

Size-groups
(cm.)
$62-66$
$67-71$
$72-76$
Total
Mean

\begin{tabular}{|c|c|}
\hline \multicolumn{2}{|c|}{ Number of hake } \\
\hline Haul I & Haul II \\
\hline I4 & I7 \\
\hline 4 & 8 \\
\hline 1 & 2 \\
\hline $\begin{array}{l}46 \\
58 \cdot I\end{array}$ & $\begin{array}{l}64 \\
58 \cdot 9\end{array}$ \\
\hline
\end{tabular}

The data given for each population in Table I have been summed for each month and are plotted in the graph in Text-fig. 4. It can be seen that there was never, during any month, an overlap of the ranges of any two populations except during December I952 and January and February 1953, when a special effort had been made to obtain as many hake as possible, some 580 being caught. Because these monthly samples are considerably larger than the others, their ranges do overlap and have therefore not been added to Text-fig. 4; for these months, only the mean lengths and standard deviations 


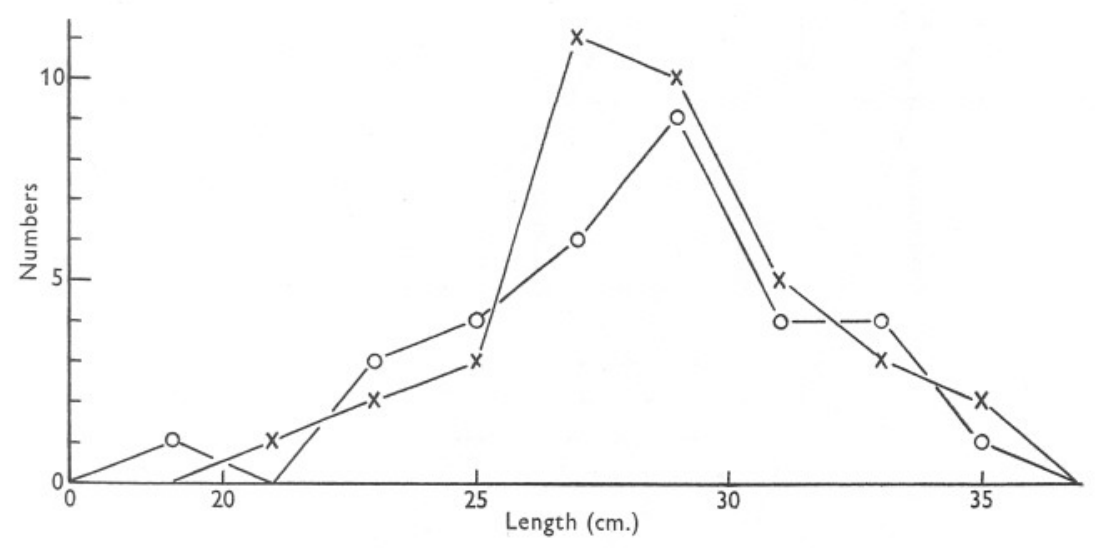

Text-fig. 3. Length-frequency distributions of hake taken in series III. $\times$, Large mesh; o, Small mesh.

Table IV. Series III Size-Frequency Distribution, IlLUSTRATED IN TEXT-FIG. 3

Size groups

(cm.)
$18-19$
$20-21$
$22-23$
$24-25$
$26-27$
$28-29$

Large mesh Small mesh

I
2
3
II
IO

\begin{tabular}{l} 
I \\
\hline 3 \\
4 \\
6 \\
9
\end{tabular}

Size groups
(cm.)
$30-31$
$32-33$
$34-35$
Total
Mean

Large mesh Small mesh

$\begin{array}{cc}5 & 4 \\ 3 & 4 \\ 2 & \mathrm{I} \\ 37 & 32 \\ 27 \cdot 9 & 27 \cdot 6\end{array}$

Table V. Mean Lengths of each Population at Various Ages, Obtained by Inspection of Text-Fig. 4, Together with the Mean Lengths DURING FEBRUARY 1953

\begin{tabular}{|c|c|c|c|c|c|c|}
\hline \multirow[b]{2}{*}{ Population } & \multirow[b]{2}{*}{ Hatched } & \multicolumn{4}{|c|}{ Mean length (cm.) at } & \multirow{2}{*}{$\begin{array}{l}\text { Length, } \\
\text { Feb. I953 }\end{array}$} \\
\hline & & I year & 2 years & 3 years & 4 years & \\
\hline e & I948 & $18 \cdot 3$ & $44 \cdot 0$ & $6 I$ & c. 70 & $77 \cdot 8$ \\
\hline$d$ & I949 & 24.0 & $40 \cdot 5$ & $56 \cdot 5$ & - & $67 \cdot 8$ \\
\hline$c$ & I950 & c. 28 & c. 45 & - & - & $53 \cdot 3$ \\
\hline$b$ & I95I & c. $18-20$ & 4 & - & 一 & $33 \cdot 6$ \\
\hline$a$ & 1952 & - & - & - & - & 13.5 \\
\hline Mean & - & $22 \cdot 3$ & $43 \cdot 2$ & $58 \cdot 7$ & 70 & - \\
\hline
\end{tabular}

are given. The graph shows that the populations are distinct and homogeneous groups, and the growth rate of the hake may be deduced from the growth rate of each population, and this information, extracted from Text-fig. 4, is given in Table V.

The data for each February of 1950, 1951, 1952 and 1953 are plotted in Text-fig. 5, which confirms that the populations are distinct, except in February I953 when population $e$ (marked with a dashed line) was masked 


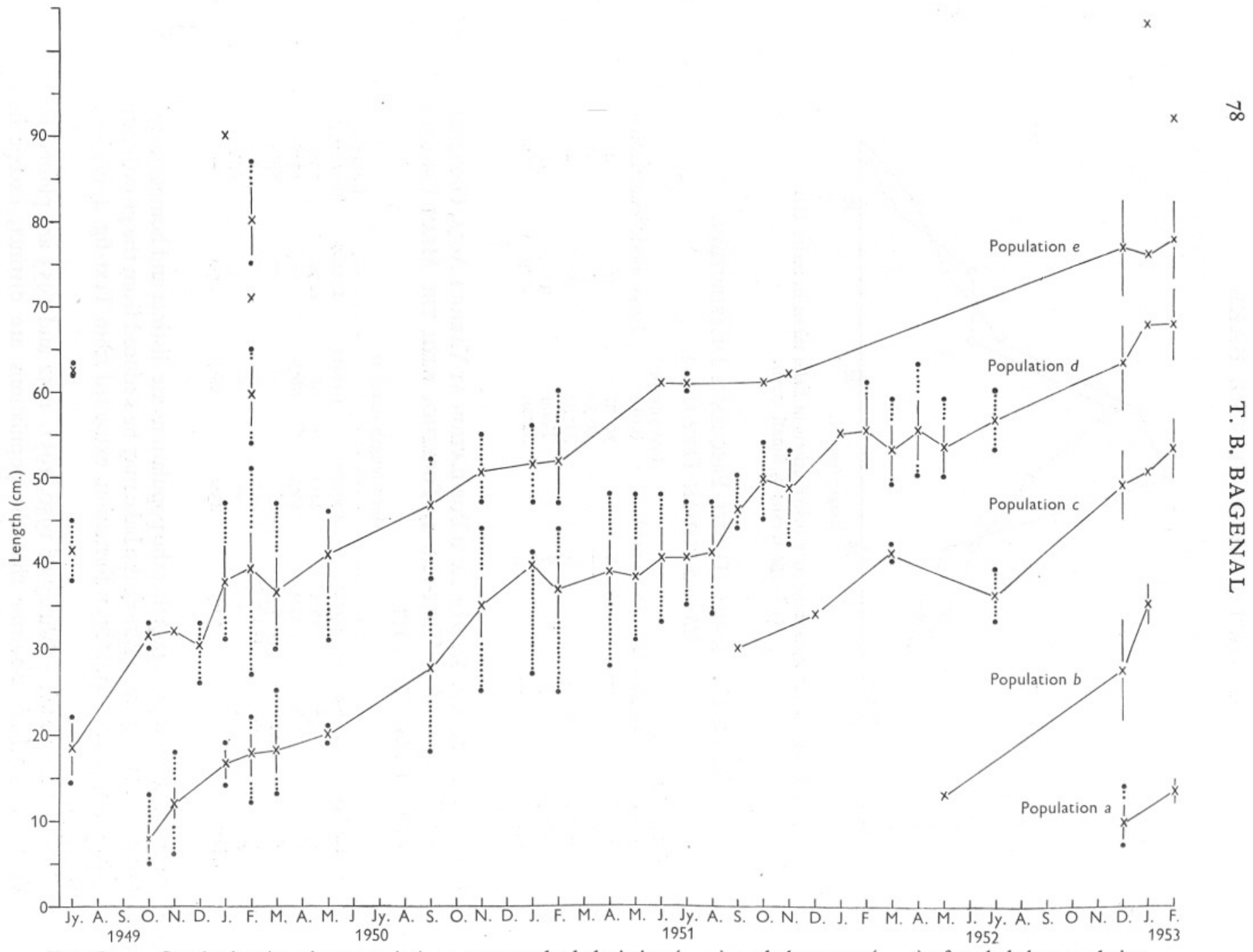

Text-fig. 4. Graph showing the mean $(\times), \pm$ one standard deviation $(-)$, and the range (......) of each hake population plotted against the month of capture. 
by population $d$, but this was discovered only from the results of otolith readings. With large samples of relatively large fish, it is considerably more

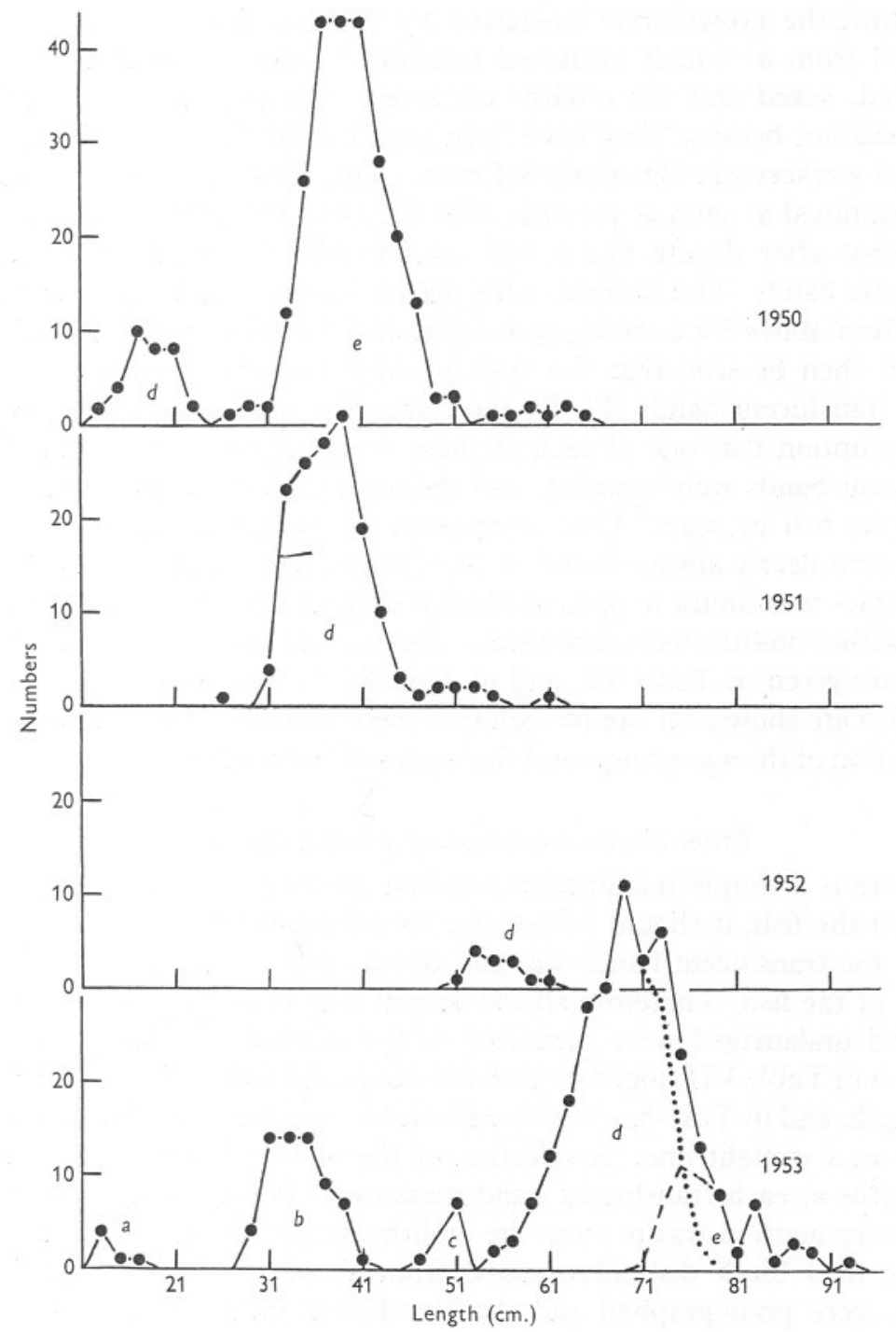

Text-fig. 5. Length-frequency diagram of hake caught each February of I950, I95 I, I952, and 1953. The letters $a-e$ refer to the populations shown in Table I.

difficult to pick out the various age-classes, as, with increasing age, there is a greater possibility of overlap, and with increasing numbers, there is a greater possibility of catching the extremes of range. 


\section{From direct Otolith Readings}

In December 1952 it was decided that corroborative evidence was needed to confirm the growth rate suggested by the size frequencies. Hake were obtained from as widely scattered localities in the Clyde area as possible, measured, sexed and the otoliths extracted. Otoliths were chosen for age determination because they have been found to be the most satisfactory by previous workers (see Birtwistle \& Lewis, I925; Hickling, I933). The otoliths were examined as soon as possible after they had been extracted since it was found that after drying out it was considerably more difficult to see any concentric bands. The otoliths were placed in water in a black dish illuminated from above by a strong spot-light, and examined with the naked eye. It could then be seen that the otoliths exhibited opaque zones with intervening translucent bands (Pl. I); the centre was almost always opaque. On the assumption that one of each of these structures is formed annually, the translucent bands were counted, and the number found was taken to be the age of the fish in years. This assumption is reasonable since fish of equal length were nearly always found to be of equal age, and the age structure of the samples was found to agree with that obtained by other methods.

Altogether otoliths were taken from 585 fish and the results of their examination are given in Table VI, and in Text-fig. 6, where the size frequencies of the fish are shown. It can be seen that there is close agreement between the distribution of the age-groups and the modes of the total size-frequency graph.

\section{From Back-calculation of Otolith Readings}

If there is a simple relationship between the length of the otolith and the length of the fish, it should be possible to calculate the size of the fish when each of the translucent bands was laid down; that is once a year throughout the life of the fish. Therefore all the overall lengths of the otoliths that were extracted undamaged were measured to the nearest millimetre; the results are given in Table VII, together with the range and mean of the corresponding fish length, and in Text-fig. 7, where it can be seen that the points lie approximately on a straight line. A selection of the otoliths were re-examined and the lengths at each translucent band measured. It was found that the most satisfactory method was to store the otoliths in alcohol and examine them in creosote in a black dish illuminated from above. Using this method the otoliths were photographed and the translucent bands measured from the image of the negative placed in an enlarger.

It was found sometimes that the rings, though easily counted, were not necessarily clear on the long axis of the otolith; for this reason readings were not obtained from all the otoliths examined.

From these measurements the sizes of the fish during the formation of each ring were calculated, with the results given in Table VIII. In considering them 


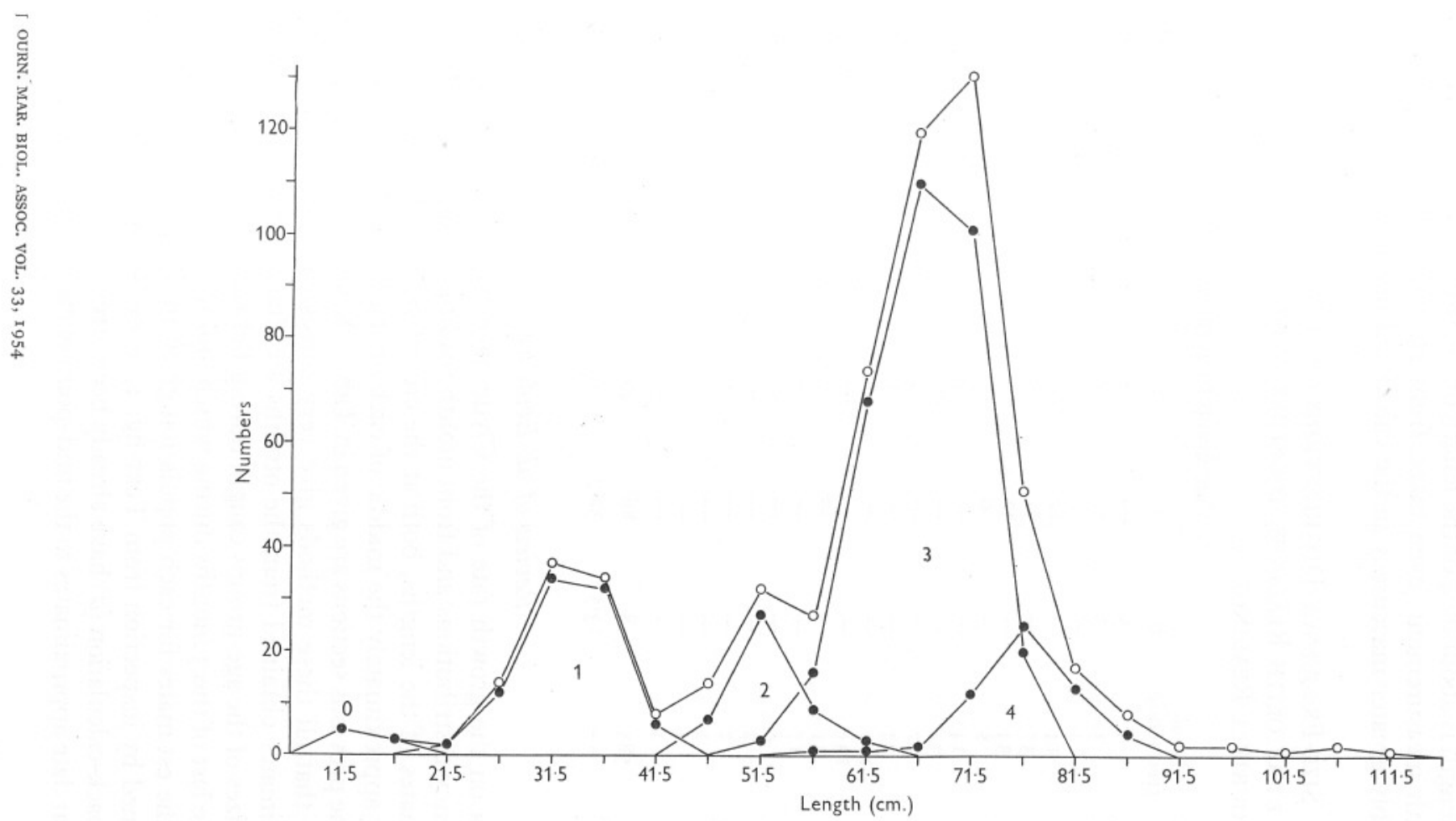

Text-fig. 6. Length-frequency diagrams of the various hake age-groups, $\mathrm{O}-4(\bullet)$, as indicated by their otoliths, and of all the hake examined (o). 
it must be remembered, first, that for each size of otolith there is often a considerable range in size of fish (see Table VII); and secondly that the otolith length is about 0.04 of the length of the fish, so that any inaccuracy in the otolith measurement (even taken from an enlarged picture) leads to a considerably greater inaccuracy in the calculated fish length.

Table Vi. Size-Frequency Distributions of Hake Age-Classes, DeterMined by Otolith Readings, TOGETHER With Total Size-Frequency and DoubTful Readings

\begin{tabular}{|c|c|c|c|c|c|c|c|}
\hline \multirow{2}{*}{$\begin{array}{l}\text { Size-groups } \\
\text { (cm.) }\end{array}$} & \multirow{2}{*}{$\begin{array}{c}\text { Total } \\
\text { frequency }\end{array}$} & \multicolumn{5}{|c|}{ Age-group frequencies } & \multirow{2}{*}{$\begin{array}{l}\text { Illegible } \\
\text { and } \\
\text { uncertain }\end{array}$} \\
\hline & & o & I & 2 & 3 & 4 & \\
\hline $9-13$ & 5 & 5 & - & - & - & - & - \\
\hline $14-18$ & 3 & 3 & - & - & - & - & - \\
\hline $19-23$ & 2 & - & 2 & - & - & - & - \\
\hline $24-28$ & I4 & - & 12 & - & - & - & 2 \\
\hline $29-33$ & 37 & - & 34 & - & - & - & 3 \\
\hline $34-3^{8}$ & 34 & - & 32 & - & - & - & 2 \\
\hline $39-43$ & 8 & - & 6 & - & - & - & 2 \\
\hline $44-48$ & I4 & - & - & 7 & - & - & 7 \\
\hline $49-53$ & 32 & - & - & 27 & 3 & - & 2 \\
\hline $54-58$ & 27 & - & - & 9 & 16 & I & I \\
\hline $59-63$ & 74 & - & - & 3 & 68 & I & 2 \\
\hline $64-68$ & 120 & - & - & - & IIO & 2 & 8 \\
\hline $69-73$ & I3I & - & - & - & IOI & 12 & 18 \\
\hline $74-78$ & $5 \mathrm{I}$ & - & - & - & 20 & 25 & 6 \\
\hline $79-83$ & I7 & - & - & - & - & 13 & 4 \\
\hline $84-88$ & 8 & - & - & - & - & 4 & 4 \\
\hline $89-93$ & 2 & - & - & - & - & - & 2 \\
\hline $94-98$ & 2 & - & - & - & - & - & 2 \\
\hline 99-103 & I & - & - & - & - & - & I \\
\hline $104-108$ & 2 & - & - & - & - & - & 2 \\
\hline I09-II3 & I & - & - & - & - & - & I \\
\hline Total & 585 & 8 & 86 & 46 & 318 & 58 & 69 \\
\hline Mean & - & 13.5 & $32 \cdot 7$ & $5 \mathrm{r} \cdot 8$ & $66 \cdot 5$ & $76 \cdot 0$ & - \\
\hline
\end{tabular}

The data on the growth rate of the Clyde hake have been obtained from size-frequency distributions and from otolith readings; and each method has given estimates of the lengths, both at the end of each of the first 4 years of life, and at approximately the middle of each of the first 5 years. Data summarizing the previous sections are given in Table IX, and in Text-fig. 8. It will be noticed that all these methods give very consistent results. The slightly smaller estimates obtained from the otoliths are due to several factors: first, the mean sizes of the age-groups caught during February 1953 ( $a$ in Table IX) apply to the last of the 3 months during which otoliths were extracted $(c)$; and secondly, the estimates for each population given in Table V ( $b$ in Table IX) were obtained by inspection from Text-fig. 4 , while the possibilities of errors in otolith back-calculation $(d)$ have already been stressed; and thirdly, it is not certain what date approximates to the mid-point of each growth-year for Clyde 
hake. The otoliths of only one hake, a male of $25 \mathrm{~cm}$. caught on 2 I January I953, have suggested a growth rate which does not agree with that outlined in this paper. The otolith showed three very clear translucent bands which were quite unlike subsidiary rings. Unfortunately, the fish was not kept after the otolith was removed so it was impossible to determine what had caused the slow growth.

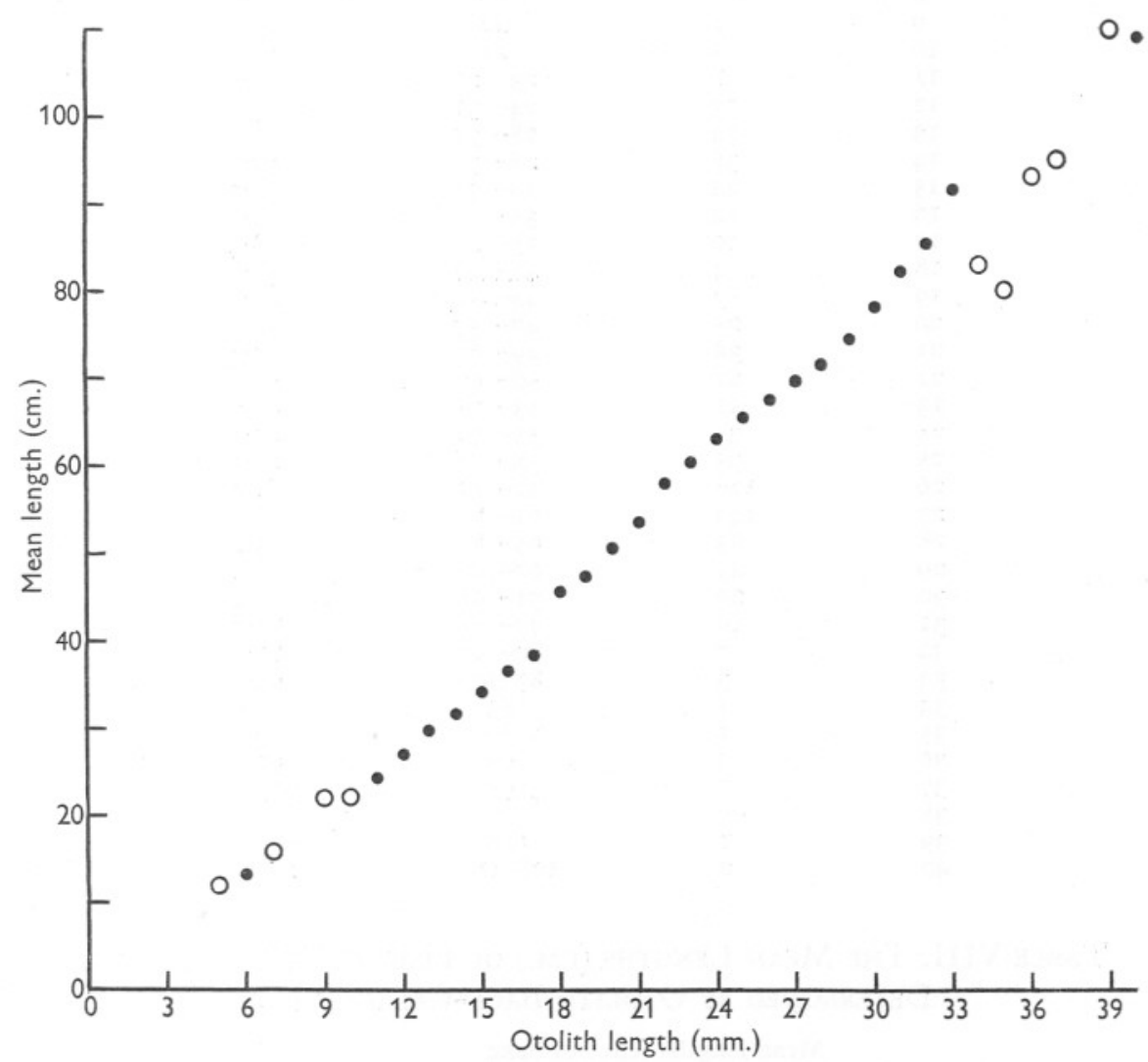

Text-fig. 7. The relationship between the length of hake and the length of their otoliths. o, only one otolith examined.

\section{Comparison with Previous Studies}

When le Danois (1920) published his summary of the existing knowledge of the hake, it was clear that at that time very little was known about the growth rate. The first work on this was by Belloc (1923), who examined scales from 264 fish obtained from three localities: Morocco, the Bay of Biscay and south of Ireland, and he suggested that there are racial differences in the growth rate in the three regions. Later, he republished this data adding some observations 


\section{Table VII. Otolith Size-Frequency with ASSOCIATED FISH LENGTHS}

Otolith
length
5
6
7
7
8
9
I0
II
12
13
14
15
16
16
17
18
19
20
21
22
23
24
25
26
27
28
29
30
31
32
33
34
35
36
37
38
39
40

\begin{tabular}{r} 
Freque \\
$\mathrm{I}$ \\
8 \\
$\mathrm{I}$ \\
\hline $\mathrm{I}$ \\
$\mathrm{I}$ \\
$\mathrm{I}$ \\
8 \\
$\mathrm{I} 3$ \\
$\mathrm{I}$ \\
38 \\
44 \\
44 \\
$\mathrm{I}$ \\
$\mathrm{I}$ \\
4 \\
$\mathrm{I3}$ \\
25 \\
38 \\
22 \\
51 \\
75 \\
93 \\
$\mathrm{I} 26$ \\
$\mathrm{I} 43$ \\
83 \\
49 \\
23 \\
$\mathrm{I}$ \\
7 \\
3 \\
3 \\
$\mathrm{I}$ \\
$\mathrm{I}$ \\
$\mathrm{I}$ \\
$\mathrm{I}$ \\
\hline $\mathrm{I}$ \\
2 \\
\end{tabular}

Range of fish length (cm.)

$$
\begin{gathered}
\text { I2 } \\
\text { I3-I4 } \\
\text { I6 } \\
- \\
22 \\
22 \\
23-27 \\
24-31 \\
28-31 \\
28-36 \\
30-38 \\
35-40 \\
35-43 \\
45-46 \\
44-51 \\
47-57 \\
49-67 \\
50-67 \\
53-71 \\
55-74 \\
55-76 \\
52-82 \\
61-82 \\
65-80 \\
67-98 \\
71-98 \\
77-88 \\
80-92 \\
87-101 \\
83 \\
80 \\
93 \\
95 \\
\text { II } \\
\text { I08-IIO } \\
\end{gathered}
$$

\begin{tabular}{|c|c|c|c|c|c|c|c|c|c|}
\hline \multirow{3}{*}{$\underset{\text { (years) }}{\text { Age }}$} & & \multicolumn{6}{|c|}{$\begin{array}{l}\text { Mean lengths (cm.) of hake } \\
\text { calculated from otoliths showing }\end{array}$} & \multirow{3}{*}{$\begin{array}{l}\text { Mean } \\
\text { length } \\
\text { (cm.) }\end{array}$} & \multirow{3}{*}{$\begin{array}{l}\text { Grand } \\
\text { mean } \\
\text { length } \\
\text { (cm.) }\end{array}$} \\
\hline & & \multicolumn{2}{|c|}{$\begin{array}{l}\text { Two translucent } \\
\text { bands }\end{array}$} & \multicolumn{2}{|c|}{$\begin{array}{l}\text { Three translucent } \\
\text { bands }\end{array}$} & \multicolumn{2}{|c|}{$\begin{array}{l}\text { Four translucent } \\
\text { bands }\end{array}$} & & \\
\hline & & No. & Length & No. & Length & No. & Length & & \\
\hline I & $\begin{array}{l}\hat{g} \\
\phi+\end{array}$ & $\begin{array}{l}5 \\
6\end{array}$ & $\begin{array}{l}22 \cdot 22 \\
22 \cdot 16\end{array}$ & $\begin{array}{l}23 \\
44\end{array}$ & $\begin{array}{l}22 \cdot 29 \\
22 \cdot 32\end{array}$ & $\begin{array}{l}3 \\
7\end{array}$ & $\begin{array}{l}22 \cdot 77 \\
24 \cdot 64\end{array}$ & $\begin{array}{l}22 \cdot 14 \\
23 \cdot 04\end{array}$ & $22 \cdot 59$ \\
\hline 2 & $\begin{array}{l}0 \\
0 \\
+\end{array}$ & $\begin{array}{l}4 \\
6\end{array}$ & $\begin{array}{l}39 \cdot 04 \\
38 \cdot 08\end{array}$ & $\begin{array}{l}23 \\
46\end{array}$ & $\begin{array}{l}43 \cdot 49 \\
43 \cdot 44\end{array}$ & $\begin{array}{l}2 \\
7\end{array}$ & $\begin{array}{l}43 \cdot 09 \\
47 \cdot 77\end{array}$ & $\left.\begin{array}{l}4 r \cdot 87 \\
43 \cdot 10\end{array}\right\}$ & $42 \cdot 48$ \\
\hline 3 & $\begin{array}{l}0 \\
0 \\
0\end{array}$ & $\overline{-}$ & $\overline{-}$ & $\begin{array}{r}7 \\
22\end{array}$ & $\begin{array}{l}54 \cdot 42 \\
58 \cdot 22\end{array}$ & $\begin{array}{l}3 \\
6\end{array}$ & $\begin{array}{l}58 \cdot \mathrm{II} \\
59 \cdot 34\end{array}$ & $\begin{array}{l}56 \cdot 26 \\
58 \cdot 78\end{array}$ & $57 \cdot 52$ \\
\hline 4 & ô & - & 二 & - & 二 & $\begin{array}{l}\text { I } \\
3\end{array}$ & $\begin{array}{l}65.94 \\
72 \cdot 58\end{array}$ & $\left.\begin{array}{c}65 \cdot 94 \\
72 \cdot 58\end{array}\right\}$ & $69 \cdot 26$ \\
\hline
\end{tabular}

Mean length of fish (cm.)

$$
\begin{aligned}
& \text { I2 } \\
& 13 \cdot 2 \\
& 16 \\
& -1 \\
& 22 \\
& 22 \\
& 24 \cdot 4 \\
& 27 \cdot 0 \\
& 29 \cdot 8 \\
& 31 \cdot 8 \\
& 34 \cdot 3 \\
& 36 \cdot 7 \\
& 38 \cdot 4 \\
& 45 \cdot 5 \\
& 47 \cdot 2 \\
& 50 \cdot 6 \\
& 53 \cdot 4 \\
& 58 \cdot 0 \\
& 60 \cdot 3 \\
& 63 \cdot 1 \\
& 65 \cdot 8 \\
& 67 \cdot 3 \\
& 70 \cdot 0 \\
& 71 \cdot 6 \\
& 74 \cdot 5 \\
& 78 \cdot 1 \\
& 82 \cdot 1 \\
& 85 \cdot 6 \\
& 91 \cdot 7 \\
& 83 \\
& 80 \\
& 93 \\
& 95 \\
& 110 \\
& 109 \\
&
\end{aligned}
$$

Table VIII. The Mean Lengths (CM.) of Fish of Various Ages as DETERMINED By OTOLITH BACK-CALCULATION 
on a slow-growing stock found in the Mediterranean (Belloc, I929). His results are given in Table $\mathrm{X}$ and compared with the Clyde results in Text-fig. 9. It can be seen that even the fastest-growing race, those from the Morocco Coast,

Table IX. Summary of all Evidence of Mean Fish Lengths at Different Ages; Illustrated In TeXt-Fig. 8

From length frequencies

$$
\text { Age (years) } \ldots \text { O+ } \quad \text { I } \quad \text { I }+\quad 2 \quad 2+\quad 3 \quad 3+\quad 4 \quad 4+
$$

$\begin{array}{llllllllllll}\text { (a) Mean length, Feb. I953 } & \text { Mean } & 13 \cdot 5 & - & 33 \cdot 6 & - & 53 \cdot 3 & - & 67 \cdot 8 & - & 77 \cdot 8 \\ \text { (b) Mean of all populations (Table V) } & - & 22 \cdot 3 & - & 43 \cdot 2 & - & 58 \cdot 7 & - & 70 \cdot 0 & -\end{array}$

From otoliths

(c) Direct reading (Table VI)

(d) Back-calculations (Table VIII) Mean

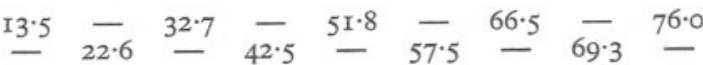

$$
\begin{aligned}
& \begin{array}{lllllllll}
\text { I3.5 } & 22.4 & 33 . \mathrm{I} & 42.8 & 52.5 & 58 . \mathrm{I} & 67 . \mathrm{I} & 69.6 & 76.9
\end{array}
\end{aligned}
$$

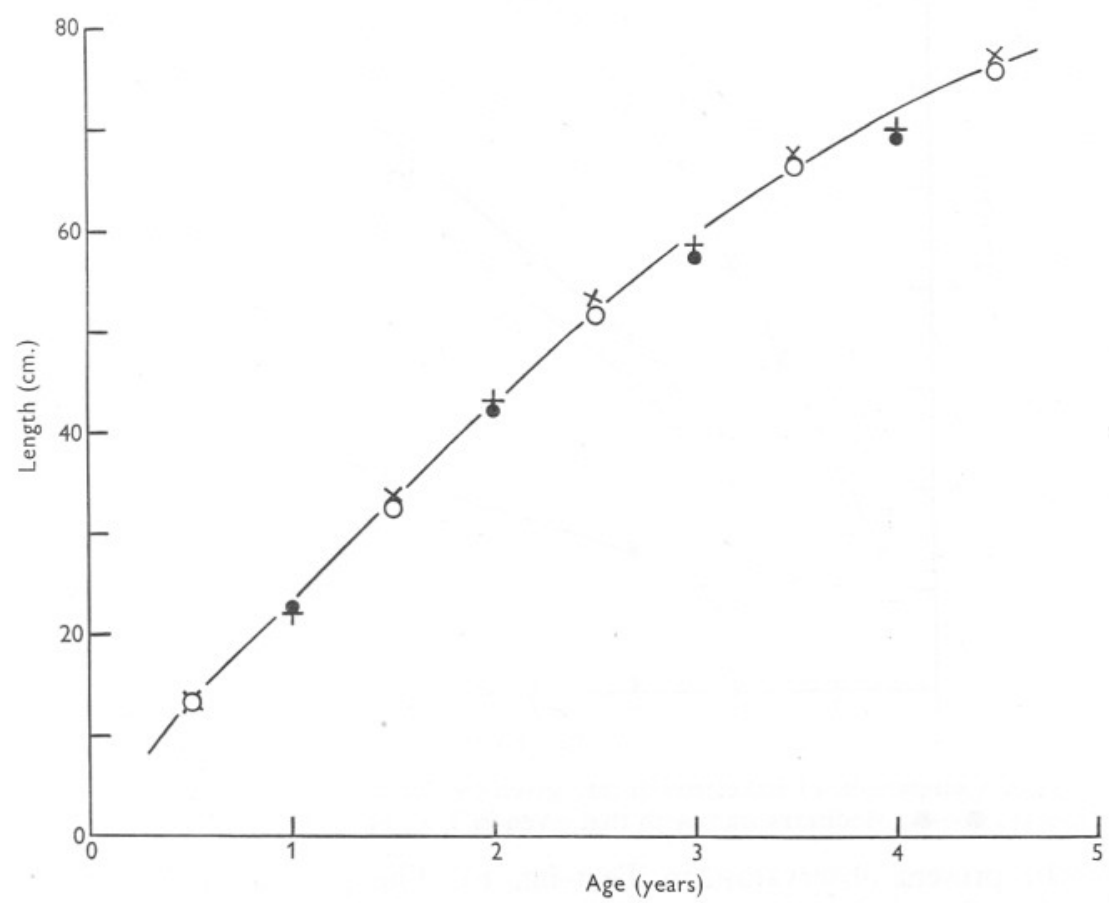

Text-fig. 8. Summary of growth of hake from all evidence. + , from length-frequency measurements, mean of all populations; $\times$, from length frequencies, mean lengths in February I953; 0, from direct otolith readings, mean lengths of each age-group; , from back-calculation of otoliths, mean of all populations at each age.

only reach a size of about $79 \mathrm{~cm}$., 9 years after hatching, whereas the Clyde hake reach a comparable size during their fifth year.

The first British work published was that of Birtwistle \& Lewis (1925), who studied the hake in the Irish Sea and to the north-west and south-west of 
Ireland. These authors used scales and otoliths for age determination; although they found scales very difficult to read, they were forced to use them for all marketable fish. Their results are given in Table XI and compared graphically

Table X. Mean Lengths (CM.) of Hake of Various Ages from Four REgions, ACCORDING TO BELLOC

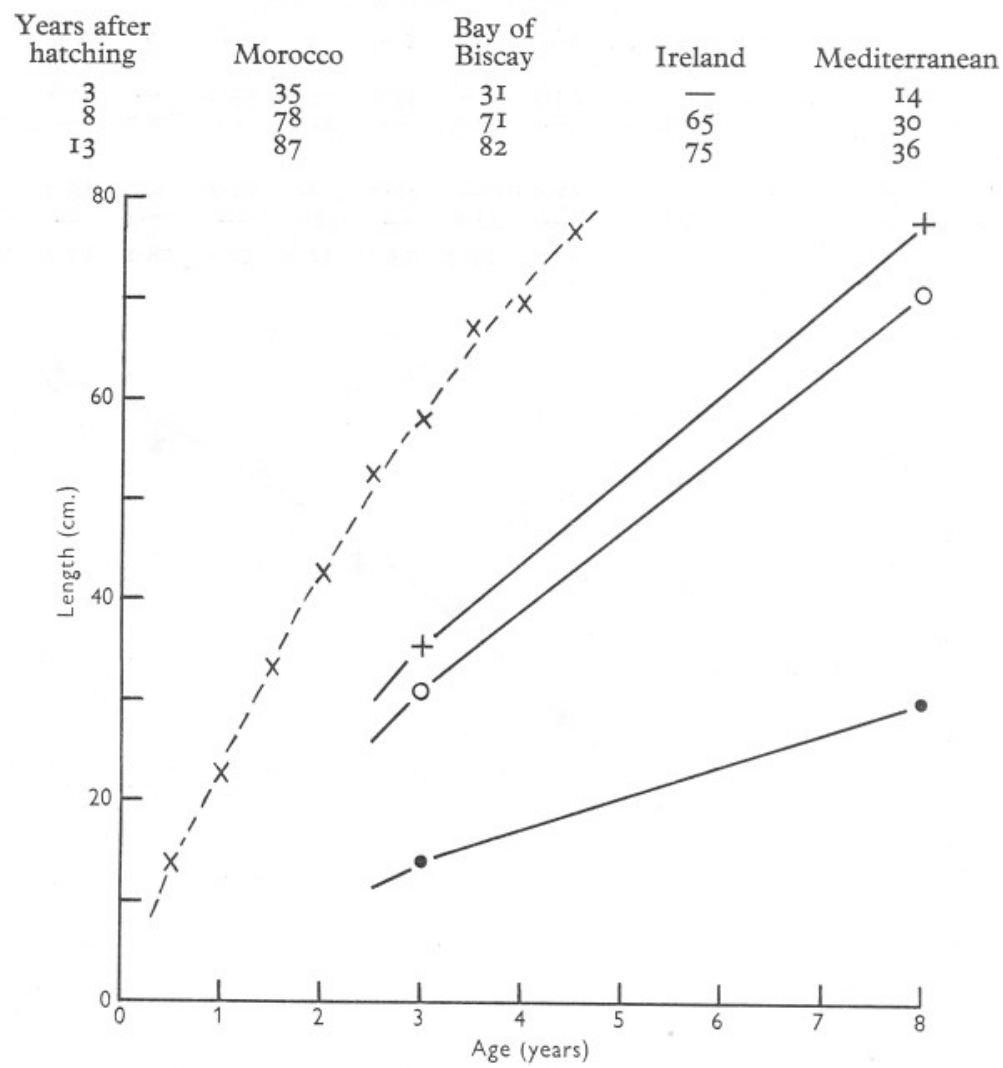

Text-fig. 9. Comparison of hake growth rate given by Belloc $(+-+$, Morocco; $0-0$, Bay of Biscay; - Mediterranean) with that given in Text-fig. 8 for the Clyde $(\times---x)$.

with the present observation in Text-fig. Io. The growth rates of the fish studied by Birtwistle \& Lewis are all slower than that described in the present paper, although the findings for the Irish Sea are quite comparable to those of the Clyde.

In 1933 Hickling published the fourth part of his 'Natural History of the Hake', in which he considers age determination and growth rate. His results are based on the measurements of 54,560 hake, of which he examined the otoliths of 25,930; as he aptly remarks 'We therefore have plentiful material on which to base our results'. These results are shown in Table XII (taken 


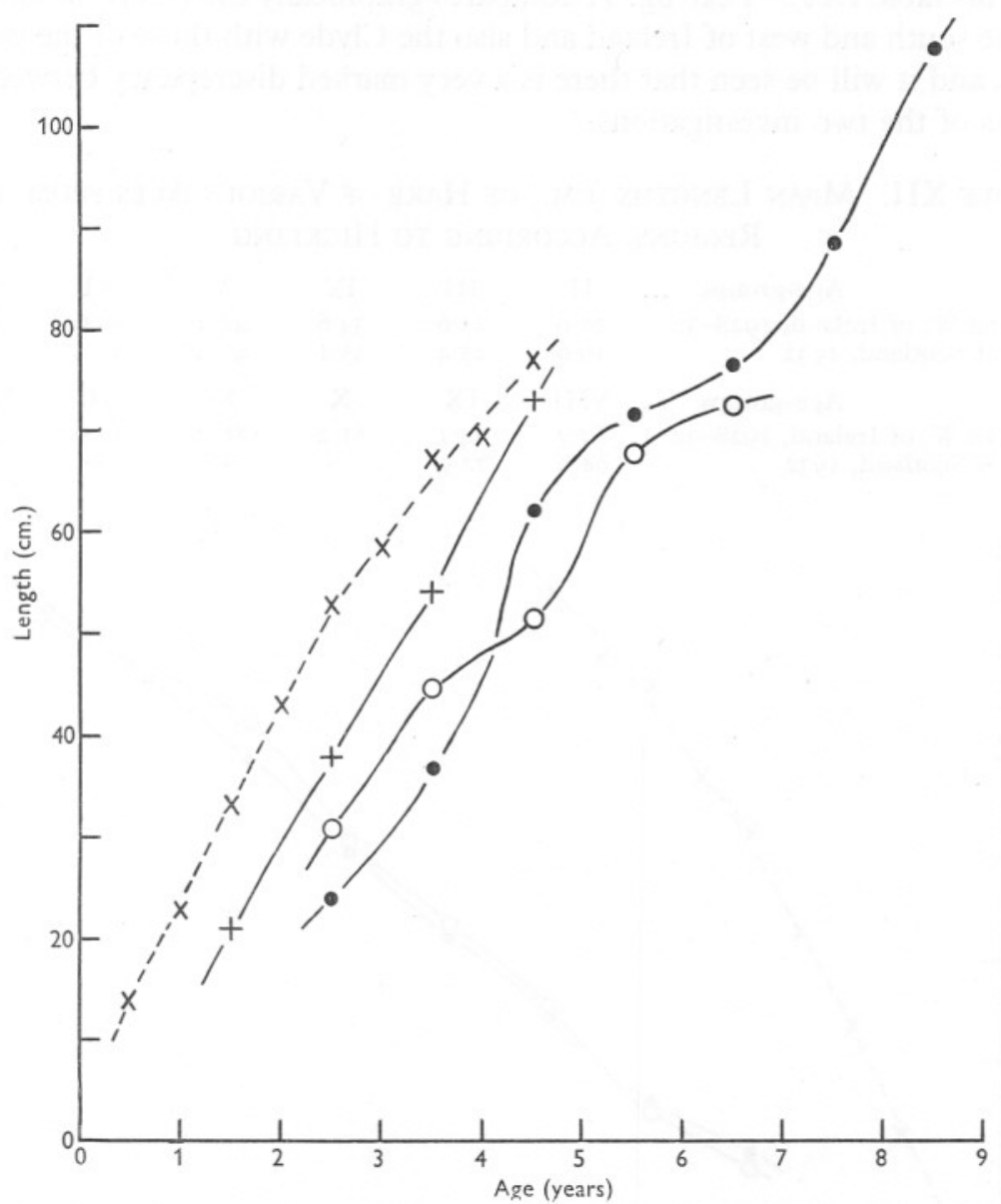

Text-fig. Io. Comparison of hake growth rate given by Birtwistle \& Lewis $(+-+$, Irish Sea; $\longrightarrow$, S.W. Ireland; o-0, N.W. Ireland) with that given in Text-fig. 8 for the Clyde $(x-\cdots)$.

Table Xi. Mean Lengths (CM.) of Hake of Various Ages from Three Regions, ACCording to BirTwistle \& Lewis

$\begin{array}{cccc}\text { Age } & \text { Irish Sea } & \text { S.W. Ireland } & \text { N.W. Ireland } \\ \text { I } & 20 \cdot 3 & -\cdot & - \\ 2 & 37 \cdot 5 & 23 \cdot 7 & 30 \cdot 7 \\ 3 & 54 \cdot 0 & 36 \cdot 8 & 44 \cdot 3 \\ 4 & 72 \cdot 5 & 6 \cdot 9 & 51 \cdot 7 \\ 5 & - & 71 \cdot 8 & 67 \cdot 5 \\ 6 & = & 76 \cdot 3 & 72 \cdot 5 \\ 7 & - & 88 \cdot 3 & - \\ 8 & - & 107 \cdot 5 & -\end{array}$


from his table IX $c$ ). Text-fig. II compares graphically the results of Hickling for the south and west of Ireland and also the Clyde with those of the present work, and it will be seen that there is a very marked discrepancy between the results of the two investigations.

Table XiI. Mean Lengths (Cm.) of Hake of Various Ages from Two REgIONS, ACCORDING TO HiCKLING

\begin{tabular}{|c|c|c|c|c|c|c|}
\hline Age-groups $\ldots$ & II & III & IV & V & VI & VII \\
\hline $\begin{array}{l}\text { S. and W. of Ireland, I928-32 } \\
\text { W. of Scotland, I932 }\end{array}$ & $\begin{array}{l}20 \cdot 9 \\
19 \cdot 6\end{array}$ & $\begin{array}{l}25 \cdot 6 \\
25 \cdot 4\end{array}$ & $\begin{array}{l}34 \cdot 6 \\
35 \cdot I\end{array}$ & $\begin{array}{l}42 \cdot I \\
43 \cdot 2\end{array}$ & $\begin{array}{l}50 \cdot 9 \\
5 \mathrm{I} \cdot 4\end{array}$ & $\begin{array}{l}59 \cdot 8 \\
63 \cdot 4\end{array}$ \\
\hline Age-groups & VIII & IX & $\mathrm{x}$ & XI & XII & + \\
\hline $\begin{array}{l}\text { S. and W. of Ireland, } 1928-32 \\
\text { W. of Scotland, I } 932\end{array}$ & $\begin{array}{l}67 \cdot 9 \\
68 \cdot 0\end{array}$ & $\begin{array}{l}74 \cdot 1 \\
72 \cdot 9\end{array}$ & $8 \mathrm{r} \cdot 2$ & $86 \cdot 2$ & $82 \cdot 9$ & $97 \cdot 0$ \\
\hline
\end{tabular}

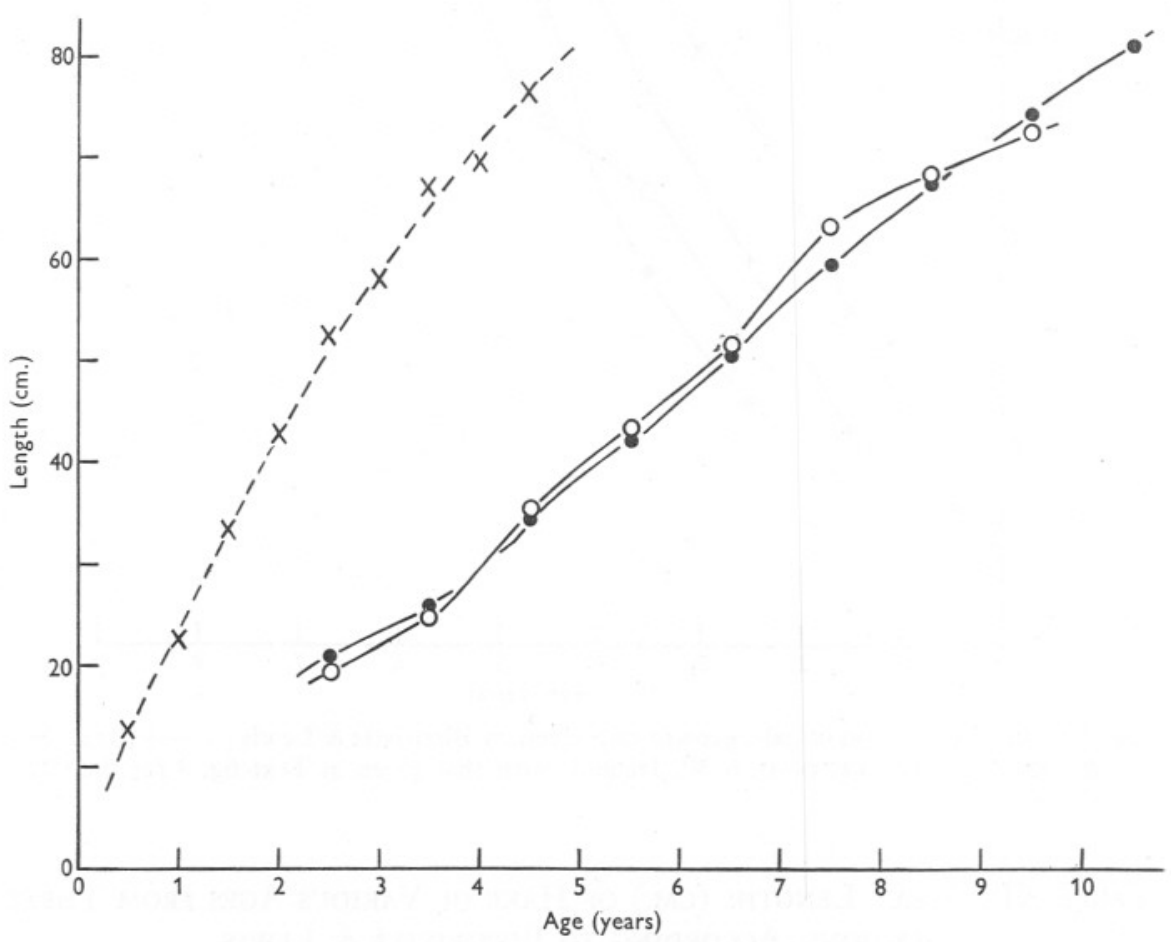

Text-fig. II. Comparison of hake growth rate given by Hickling $(\bullet-\bullet$, south and west of Ireland; $0-0$, Clyde), with that given in Text-fig. 8 for the Clyde $(x---x)$.

Hickling (I933) explained the difference between his results and those of Birtwistle \& Lewis by suggesting that the latter authors had misread the scales and halved the age of each fish, because they suggested that a check ring appears on the scale when the growth slows down in the winter, and another faint ring is formed when the summer growth recommences, so that two rings 
correspond to I year's growth. Hickling pointed out that their results agree with his if one allots one zone to each year of life of the fish, but he failed to note that Birtwistle \& Lewis did not suggest that the system of double-ringing applies to otoliths as well as to scales, and that their results for the small fish (obtained from otoliths) fit nicely to those for the larger fish obtained from scales.

Belloc (I929) maintained that he saw alternating clear and cloudy zones in the scales, and that one of each corresponds to a year's growth. Unfortunately he did not give any other supporting evidence for the growth rate he suggested; the numbers of fish caught in any month are not sufficient to provide any evidence from their size-frequency distribution. It is also unfortunate that Belloc did not state if there was a check ring, such as Birtwistle \& Lewis saw, between his clear and cloudy zones. If there was not, and the ring was represented by the cloudy zone, it would be necessary to halve the age of his fish; this would make his results more comparable to those given in this paper, and to those reported by Birtwistle \& Lewis.

Hickling's conclusions, on the other hand, are definitely based on sufficient material, and he provides adequate supporting evidence. Moreover, he illustrates his method of age determination by means of an excellent photograph of four otoliths (his figure II), and there can be little doubt that his interpretations are correct. Nevertheless, the mean annual increase in length from all sources, is given as $8.7 \mathrm{~cm}$., while elsewhere (footnote on p. 20) an account is given of the only successful hake-marking experiment; the fish grew II $7 \mathrm{~cm}$. in 8 months which would correspond to an annual increment of $17.5 \mathrm{~cm}$. No explanation is given of this discrepancy.

\section{Sexual Growth-Rate Differences}

As reported by other workers (Belloc, I929; Birtwistle \& Lewis, I925; Hickling, I933), it has been found that the female hake grow faster than the males. The mean sizes of the age-groups of the two sexes during December I952 and January and February I953 are given in Table XIII, and for two of the months the data are shown graphically in Text-fig. I2. In Table XIV comparisons are made of the sizes of the two sexes caught in the same hauls on various dates, and it can be seen that the mean length of the females becomes very significantly larger during the third year. With the 2-year-old fish, although the females are larger, only in one sample is the difference possibly statistically significant. The I-year-old fish are somewhat anomalous because in both samples the males are the larger. In the bigger haul taken on I8 February 1953, the larger size of the males is very definitely significant. In contrast, from the results of the back-calculations of the otoliths (Table VIII), it appears that it is more usual for both sexes to be of approximately the same size until they enter their third year of life when the large size of the females becomes more clearly recognizable and consistent. 

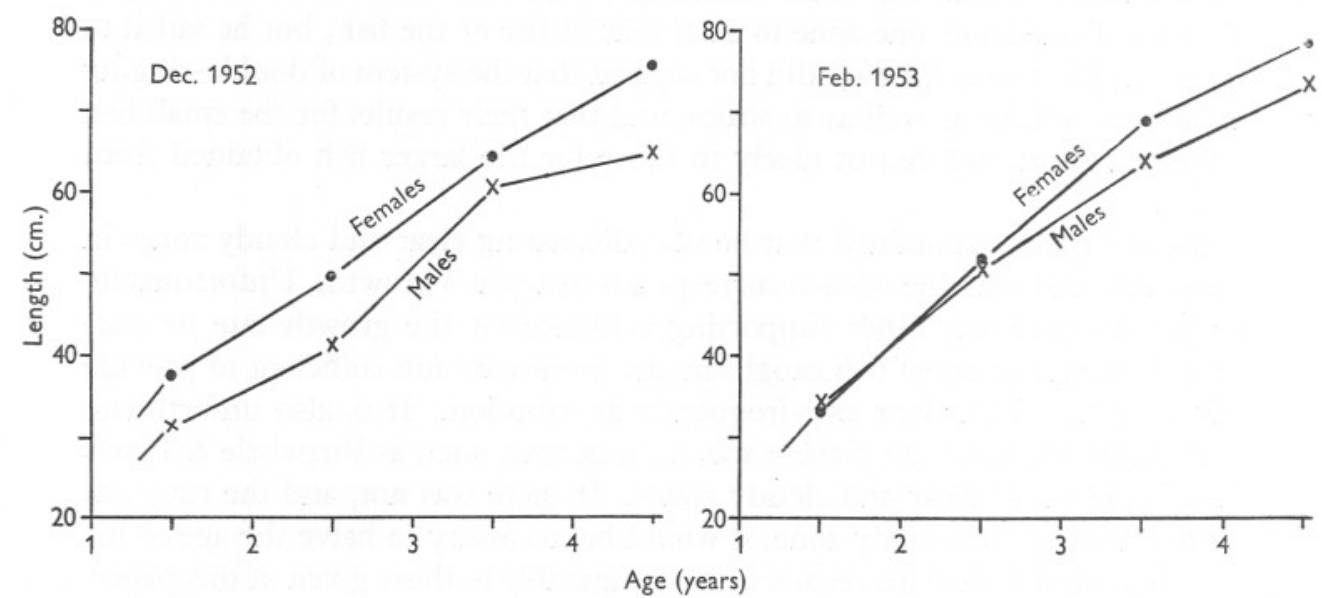

Text-fig. I2. Comparison of growth rates of male and female hake.

Table XiII. Mean Lengths (CM.) of Male and Female Hake of Various Ages DURING DeCember I952 AND JanUARY AND February I953

\begin{tabular}{|c|c|c|c|c|c|}
\hline & & I & 2 & 3 & 4 \\
\hline December & $\begin{array}{l}\hat{o} \\
\hat{q}\end{array}$ & $\begin{array}{l}3 I \cdot 0 \\
37 \cdot 5\end{array}$ & $\begin{array}{l}4 \mathrm{I} \cdot 0 \\
49^{\circ} \cdot 6\end{array}$ & $\begin{array}{l}60 \cdot 5 \\
64 \cdot 6\end{array}$ & $\begin{array}{l}64 \cdot 7 \\
75 \cdot 8\end{array}$ \\
\hline January & $\begin{array}{l}\hat{0} \\
\text { q }\end{array}$ & $\begin{array}{l}35 \cdot 7 \\
33 \cdot 5\end{array}$ & $\frac{-}{50.5}$ & $\overline{67 \cdot 7}$ & $\overline{76 \cdot 0}$ \\
\hline February & $\begin{array}{l}\hat{0} \\
+\end{array}$ & $\begin{array}{l}34 \cdot 2 \\
33 \cdot I\end{array}$ & $\begin{array}{l}50 \cdot 6 \\
52 \cdot 0\end{array}$ & $\begin{array}{l}64 \cdot 3 \\
69 \cdot 6\end{array}$ & $\begin{array}{l}74 \cdot 4 \\
79 \cdot 9\end{array}$ \\
\hline
\end{tabular}

Table XIV. Comparison of Mean Lengths (cm.) of Male and Female Hake Caught in the Same Trawl Haul

\begin{tabular}{|c|c|c|c|c|c|}
\hline \multirow[b]{2}{*}{ Date } & \multirow[b]{2}{*}{ Age } & & \\
\hline & & No. & Mean & No. & Mean \\
\hline 16. i. 53 & I & 2 & $34 \cdot 0$ & 2 & $33 \cdot 5$ \\
\hline 18. ii. 53 & I & 23 & $34 \cdot 2$ & 33 & $32 \cdot 5$ \\
\hline 18. xii. 52 & 2 & 4 & $50 \cdot 0$ & 3 & $56 \cdot 3$ \\
\hline I9. xii. 52 & 2 & II & $47 \cdot 9$ & I5 & $48 \cdot 3$ \\
\hline I3. ii. 53 & 2 & 3 & $50 \cdot 6$ & 4 & $5 \mathrm{I} \cdot 0$ \\
\hline I. xii. 52 & 3 & 3 & $5 \mathrm{I} \cdot 7$ & I4 & 68.9 \\
\hline 8. xii. 52 & 3 & I8 & $63 \cdot 3$ & 16 & $68 \cdot 7$ \\
\hline I9. xii. 52 & 3 & 20 & $59 \cdot 3$ & 59 & $62 \cdot 6$ \\
\hline I6. i. 53 & 3 & 2 & $69 \cdot 5$ & 6 & $71 \cdot 0$ \\
\hline I3. ii. 53 & 3 & 27 & 63.7 & 50 & 69.5 \\
\hline I. xii. 52 & 4 & 3 & $70 \cdot 5$ & 3 & $83 \cdot 3$ \\
\hline 3. xii. 52 & 4 & 3 & $75^{\circ} 0$ & 2 & 84.0 \\
\hline xii. 52 & 4 & I & $73 \cdot 0$ & 5 & $75 \cdot 8$ \\
\hline 3. ii. 53 & 4 & 7 & $73 \cdot 3$ & 7 & $80 \cdot 0$ \\
\hline
\end{tabular}

\section{Difference between mean lengths}

Highly signif., $P<0.01$

Not signif., $P=0.4$

Highly signif., $P<0.0$ I Highly signif., $P<0.0$ I

Highly signif., $P<0.0$ I

Highly signif., $P<0.0$ I 


\section{Regional Size Differences in the Clyde Area}

In all parts of the Clyde area hake of a given age have been found to have a similar mean size, though a few of the minor irregularities should be noted. The hake caught at the head of Loch Fyne between Strachur and Inveraray, on I9 December I952, were consistently smaller than those of the same age caught just north of Tarbert the day before (Table XV). It is indeed very remarkable to find hake so plentiful (II 5 were caught in $\mathrm{I}_{2} \frac{\mathrm{hr}}{\mathrm{h}}$.) in such a landlocked position as Inveraray; it must be remembered that typically the species is found on the edge of the continental shelf.

Table XV. Comparison of Hake Caught off Tarbert and Inveraray

\begin{tabular}{|c|c|c|c|c|c|c|c|}
\hline Age & $\ldots$ & & & & & & \\
\hline Sex & $\ldots \hat{\delta}+q$ & $\hat{0}$ & 우 & $\widehat{0}$ & 우 & o & 우 \\
\hline $\begin{array}{l}\text { Tarbert, I8. xii. } 53 \\
\text { Inveraray, r9. xii. } 53\end{array}$ & $\begin{array}{l}24 \cdot 9 \\
37 \cdot 5\end{array}$ & $\begin{array}{l}50 \cdot 0 \\
47 \cdot 9\end{array}$ & $\begin{array}{l}56 \cdot 3 \\
48 \cdot 7\end{array}$ & $\begin{array}{l}63 \cdot 3 \\
62 \cdot 6\end{array}$ & $\begin{array}{l}68 \cdot 1 \\
59 \cdot 3\end{array}$ & $\begin{array}{l}75 \cdot 0 \\
73 \cdot 0\end{array}$ & $\begin{array}{l}84 \cdot 0 \\
75 \cdot 8\end{array}$ \\
\hline
\end{tabular}

\section{Table XVI. Length Comparison of Hake CaUght off Mountstuart AND IN BUte CHANNel}

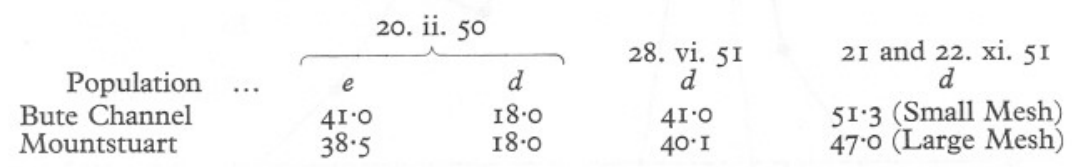

Often the depth at which the fish were caught is responsible for differences in the sizes obtained. As a general rule the larger fish are found at the greater depth. This may be seen by comparing hauls from the Mountstuart ground $(c .50 \mathrm{~m}$.) with some from the middle of Bute Channel $(c .80 \mathrm{~m}$.) $\mathrm{I}_{2} \frac{1}{2}$ miles away (Table XVI). This depth effect is seen also by comparing the Mountstuart catch of I5 February I950 (see Table I) when fish of $39 \cdot 7 \mathrm{~cm}$. mean size were caught, with the Loch Fyne catch 2 days later, at a depth of c. $200 \mathrm{~m}$., when the mean size was $44 \cdot 4 \mathrm{~cm}$.

The Mountstuart and Knock Castle grounds were both fished on 23 May I95I, when hake of Population $d$ were caught averaging 38.2 and $39 \cdot 1 \mathrm{~cm}$. respectively. The depth is approximately the same at both stations. However, the depth effect is most marked with the larger fish of $80 \mathrm{~cm}$. and above. In only one instance, when one fish was obtained, have populations averaging $80 \mathrm{~cm}$. and more been caught elsewhere than in the deep water of Loch Fyne and on both sides of Arran.

\section{Growth Rate in other Scottish Areas}

Through a kind invitation from the Marine Laboratory of the Scottish Home Department it was possible to join the F.R.S. Explorer on a west 
Scotland cruise during June I952, and thanks are due to Dr B. B. Rae for permission to use the hake length data that were obtained.

Hauls were taken at stations scattered round the north and west Scottish coasts, together with a few in the Moray Firth area and the Irish Sea. The hake lengths, measured to the nearest centimetre, have been grouped into $5 \mathrm{~cm}$. classes and the length distributions summed for seven regions. These data are given in Table XVII, and Text-fig. I3, where Clyde figures for May-plusJuly are also plotted for comparison.

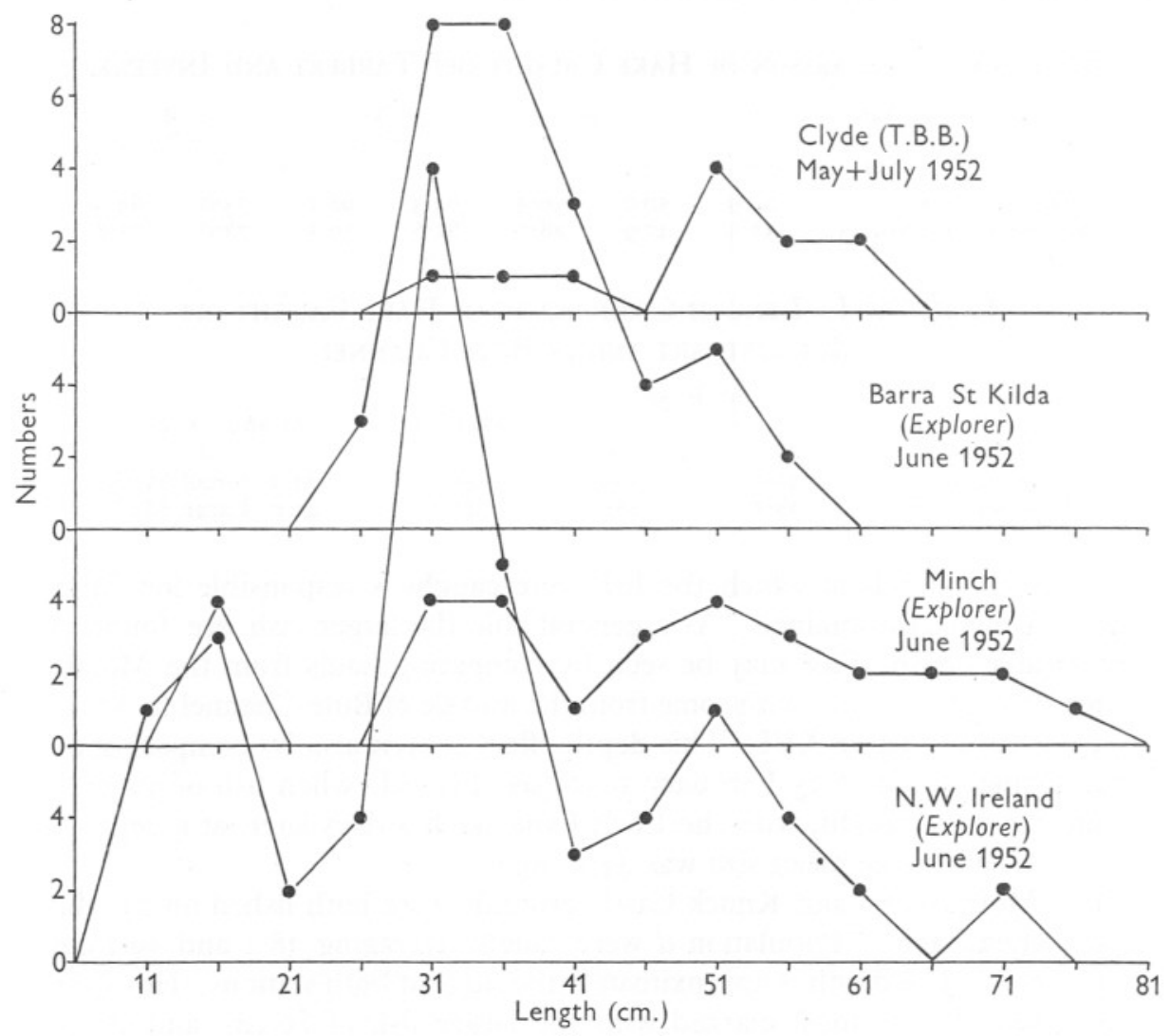

Text-fig. 13. Length-frequency diagrams of hake from three of the Scottish areas (F.R.S. Explorer, June I952), and from the Clyde during May and July 1952.

The size frequencies suggest that there are 5 year-classes present; the means of each have been calculated and are given in Table XVIII.

The yearly increments obtained from Tables XVIII and IX are given in Table XIX; the contrast between all these results and the mean increment of $8.7 \mathrm{~cm}$./year suggested by Hickling (1933) is very marked. 
TAble XVII. Length (CM.) Frequency Distributions of HAKe from SeVEN SCOTtish Areas. F.R.S. EXPLORER Data

\begin{tabular}{|c|c|c|c|c|c|c|c|}
\hline $\begin{array}{l}\text { Length } \\
\text { (cm.) }\end{array}$ & $\begin{array}{l}\text { North } \\
\text { Sea }\end{array}$ & $\begin{array}{l}\text { N. } \\
\text { Scotland }\end{array}$ & $\begin{array}{l}\text { Barra- } \\
\text { St Kilda }\end{array}$ & Minch & $\begin{array}{l}\text { N.W. } \\
\text { Ireland }\end{array}$ & Clyde & $\begin{array}{c}\text { Irish } \\
\text { Sea }\end{array}$ \\
\hline IO-I3 & - & - & - & - & 7 & - & - \\
\hline $14-18$ & - & - & - & 4 & 9 & - & - \\
\hline $19-23$ & - & - & - & - & 2 & - & - \\
\hline $24-28$ & - & - & 3 & - & 4 & - & - \\
\hline $29-33$ & I & - & I4 & 4 & 22 & - & - \\
\hline $34-38$ & I & I & I4 & 4 & II & - & - \\
\hline $39-43$ & - & - & 9 & I & 3 & - & - \\
\hline $44-48$ & - & I & 4 & 3 & 4 & - & - \\
\hline $49-53$ & - & 3 & 5 & 4 & 7 & - & - \\
\hline $54-58$ & I & - & 2 & 3 & 4 & - & I \\
\hline $59-63$ & 3 & - & - & 2 & 2 & - & - \\
\hline $64-68$ & - & - & - & 2 & - & I & - \\
\hline $69-73$ & 3 & - & - & 2 & 2 & I & - \\
\hline $74-78$ & I & - & - & I & - & - & - \\
\hline $79-83$ & 2 & - & - & - & - & - & - \\
\hline $84-88$ & - & - & - & - & - & I & - \\
\hline
\end{tabular}

Table XVIII. Mean Lengths (CM.) of Presumed Age ClASSES FROM F.R.S. EXPLORER DATA

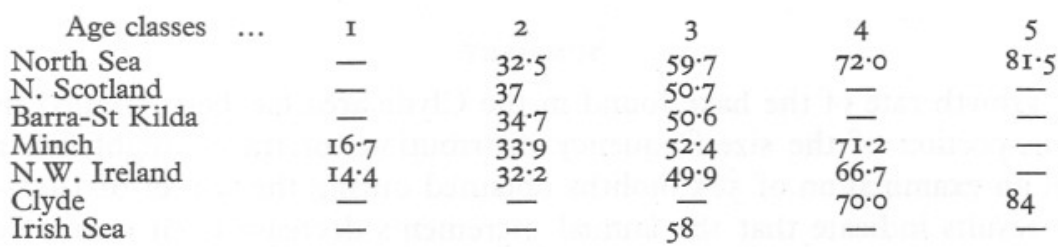

Table XIX. Presumed Yearly Increments (CM.) Calculated from Tables XVIII and IX

\begin{tabular}{|c|c|c|c|c|}
\hline From Table XVIII & 2nd year & 3 rd year & $4^{\text {th }}$ year & 5 th year \\
\hline $\begin{array}{l}\text { North Sea } \\
\text { N. Scotland }\end{array}$ & - & $27 \cdot 2$ & $12 \cdot 3$ & $9 \cdot 5$ \\
\hline $\begin{array}{l}\text { N. Scotland } \\
\text { Barra-St Kilda }\end{array}$ & 二 & $\begin{array}{l}13.7 \\
15.9\end{array}$ & 二 & 二 \\
\hline $\begin{array}{l}\text { Barra-St Kilda } \\
\text { Minch }\end{array}$ & $17 \cdot 2$ & $\begin{array}{l}15.9 \\
18.5\end{array}$ & 18.8 & - \\
\hline $\begin{array}{l}\text { N.W. Ireland } \\
\text { Clyde }\end{array}$ & $17 \cdot 8$ & $17 \cdot 7$ & $16 \cdot 8$ & - \\
\hline \multicolumn{5}{|l|}{ From Table IX } \\
\hline Clyde & $20 \cdot 4$ & $15 \cdot 3$ & II $\cdot 5$ & - \\
\hline
\end{tabular}

\section{Discussion}

The results given in this paper, together with those of previous workers, suggest that the growth rate may be more variable than indicated by Hickling.

It seems that the methods of Birtwistle \& Lewis were quite justified and that there are marked regional variations in the growth rate, though whether these are sufficient to be considered as 'variations ethnique' (Belloc, I923) is 
open to doubt, since there is no evidence that there are not long-term variations among the same stock; indeed three authors have considered the fish from south of Ireland and have come to very different conclusions. The 'law' propounded by Belloc (I929) is that 'Le croissance du merlu varie avec la latitude. Ce poisson crôit d'autant plus rapidement qu'il vit à une latitude plus faible', and this he attributes to the water temperature, though the variations in the growth during individual years he attributes to the availability of suitable food. Hickling does not actually consider regional differences in the rate of growth, but regional differences in size at a given age, the southern fish being larger than the northern, and this he explains as being due to earlier spawning in the south. Apparent differences in growth rate in individual years were also noted, but were dismissed as being due to inconsistent sampling. A definite explanation of the fast growth rate shown in this paper cannot be given, and it can only be suggested that the rate of growth may change over a number of years. In view of this, and the recent revival of interest in the biology of the hake (see le Gall et al., 1952) it is hoped to continue the present work in the Clyde area in an attempt to pick out any possible long-term growth-rate fluctuations.

\section{SUMMARY}

The growth rate of the hake found in the Clyde area has been studied from the inspection of the size-frequency distributions of trawl-caught fish and from an examination of 585 otoliths obtained during the winter of $1952-53$. The results indicate that the annual increments decrease from over $20 \mathrm{~cm}$. per annum during the first years to about $10 \mathrm{~cm}$. at about 4 years of age.

These results are compared with those of other workers and found to be considerably greater than has been previously suggested; the nearest comparison being to those investigated in Manx water. It appears that the growth rate can vary considerably.

As reported by previous authors, the females have been found to grow faster than the males, though the difference does not become very pronounced until the third year of life.

The largest fish have been found in the deeper water of Loch Fyne, to the west of Arran and in Kilbrennan Sound, and this depth effect has also been noted elsewhere. The hake of all age-groups from the head of Loch Fyne have been found to be smaller than those off Tarbert, but except for these minor variations, the growth rate and size distribution has been found to be similar throughout the Clyde area.

A small amount of data on hake growth rate in other Scottish areas is given and these suggest that the growth rate noted in this paper is not confined to Clyde hake. 


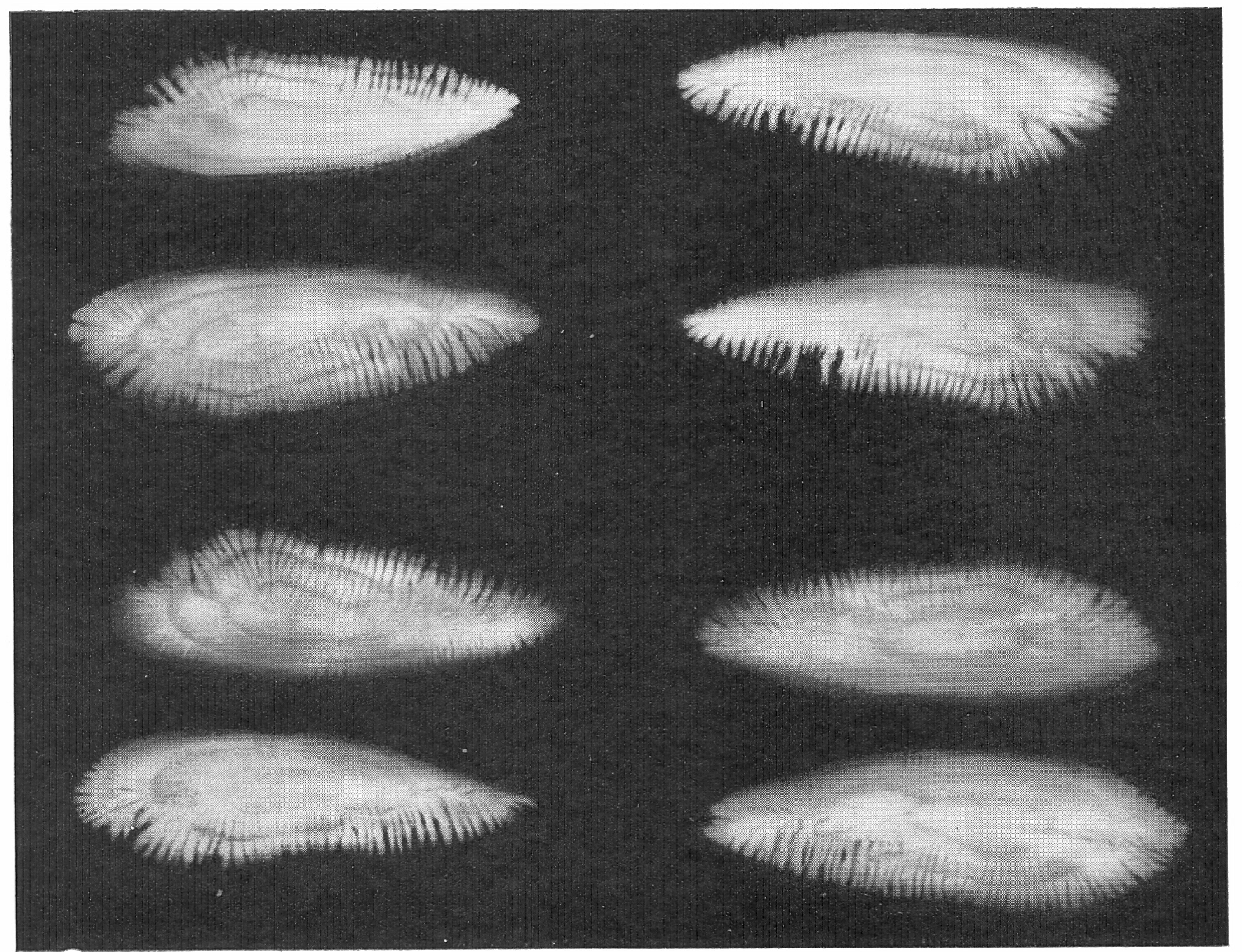




\section{REFERENCES}

BeLloc, G., I923. Note sur la croissance du Merlu, variations ethnique et sexuelles. Rapp. Cons. Explor. Mer, Vol. 3I, pp. 34-43.

I929. Étude monographique du Merlu. ze Partie. Rev. Trav. Off. Pêches marit., T. II, pp. 23I-88.

Birtwistle, W., \& Lewis, H. M., I925. Hake investigations. Rep. Lancs. Sea-Fish. Labs, 1924, pp. 36-56.

ClARK, R. S., I920. The pelagic young and early bottom stages of teleosteans. F. Mar. biol. Ass. U.K., Vol. 12, pp. 159-240.

Corbin, P. G., 1948. On the seasonal abundance of young fish. F. Mar. biol. Ass. U.K., Vol. 27, pp. 718-22.

LE DanoIs, E., I920. Le Merlu. Résumé pratique de nos connaissances sur ce poisson. Notes Off. Pêch marit., No. 2, 32 pp.

LE GALL, J. et al., I952. Contribution a l'étude du Merlu de l'Atlantique. F. Cons. int. Explor. Mer, Vol. 18, pp. 219-40.

HART, T. J., I948. The distribution and biology of hake. Biol. Rev., Vol. 23, pp. 62-80.

HickLING, C. F., I927-33. The natural history of the hake. Fish Invest., Lond., [Parts I and II] Ser. 2, Vol. Io, No. 2, 99 pp. (I927); [Part III] Ser. 2, Vol. I2, No. I, 78 pp. (I930); [Part IV] Ser. 2, Vol. I3, No. 2, I20 pp. (I933).

Russell, F. S., I930-7. On the seasonal abundance of young fish. F. Mar. biol. Ass. U.K., Vol. 16, pp. 707-22 (1930); Vol. 21, pp. 679-86 (1937).

Schmidt, J., I907. On the post-larval development of the hake (Merluccius vulgaris Flem.). Medd. Komm. Havundersøg., Kbh., Bd. 2, Nr. 7, 9 pp.

- 1909. The distribution of the pelagic fry and spawning regions of the gadoids in the North Atlantic from Iceland to Spain. Based chiefly on Danish Investigations. Rapp. Cons. Explor. Mer, Vol. Io, pp. I-229.

\section{EXPLANATION OF PLATE I}

Otoliths of presumed three-year-old Clyde-caught hake. From top to bottom, left: $\sigma^{\uparrow}, 60 \mathrm{~cm}$.;

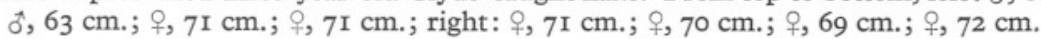

